Article

\title{
An Analysis of the Effectiveness of Greenhouse Gas Reduction Policy for Office Building Design in South Korea
}

\author{
Younghoon Kwak ${ }^{1}$, Jeong-A Kang ${ }^{2}$, Jung-Ho Huh ${ }^{1}$, Tae-Hyoung Kim ${ }^{3}$ and Young-Sun Jeong ${ }^{3, *}$ \\ 1 Department of Architecture, University of Seoul, Seoul 02504, Korea; ikyh2@uos.ac.kr (Y.K); \\ huhj0715@uos.ac.kr (J.-H.H.) \\ 2 School of Architecture, Kyonggi University, Suwon-si 16227, Gyeonggi-do 16227, Korea; \\ luvume5@kyonggi.ac.kr \\ 3 Korea Institute of Civil Engineering and Building Technology, 283 Goyangdae-ro, Ilsanseo-gu, Goyang-si, \\ Gyeonggi-do 10223, Korea; kimtaehyoung@kict.re.kr \\ * Correspondence: sunj74@kict.re.kr; Tel.: +82-31-910-0108; Fax: +82-31-910-0361
}

Received: 8 October 2019; Accepted: 13 December 2019; Published: 14 December 2019

\begin{abstract}
This paper examines the effectiveness of South Korea's policy for reducing greenhouse gas (GHG) emissions in office buildings and evaluates if national targets can be met. A sample of office buildings was categorized into two groups-conventional (Group A) and new (Group B)—based on when their construction was approved. Furthermore, data regarding the three design elements of the building envelope, that is building form, window systems, and U-values were collected. By statistically processing data of each element, reference building models were developed and a case study was conducted for each building. Design changes that were incorporated, keeping in mind the GHG reduction policy, showed $13.1 \%$ of saving energy in case 8 (reference building of Group B) than case 1 (reference building of Group A). The savings in case 8 were more than the average GHG reduction rate (12.8\%) compared to business as usual (BAU). However, case 4 (a conventional (Group A) building form with new (Group B) window systems and U-values) achieved the greatest savings in building loads. The policy to enhance insulation in new buildings to reduce GHG emissions in the building sector has prompted changes in building forms and window systems and has reduced emissions by $10 \%$, that is $3 \%$ more than the expected value. Thus, new innovations in building envelope design could achieve an average $12.8 \%$ reduction in emissions in buildings.
\end{abstract}

Keywords: greenhouse gas emissions; reduction policy; building sector; office building; reference building; building envelope

\section{Introduction}

\subsection{Background and Purpose}

As greenhouse gas (GHG) emissions continue to rise worldwide due to increasing human activities, the international community has increasingly emphasized the importance of addressing the effects of global warming. However, the results of the efforts to reduce GHG emissions have remained insignificant, so far [1]. In Europe and the United States, energy consumption in buildings accounts for approximately $40 \%$ of all the energy consumption and a third of all the GHG emissions in these regions [2-4]. The Intergovernmental Panel on Climate Change [5] reported that the global building sector is responsible for approximately $19 \%$ of all the GHG emissions. In South Korea, energy consumption in the building sector accounted for approximately $17 \%$ of the country's total energy consumption in 2015 and about $20 \%$ of all the GHG emissions [6]. As the building sector has 
been identified as the sector with the greatest potential to reduce GHG emissions in a cost-effective manner [7], innovations in the design of buildings are necessary to cope with climate change and reduce GHG emissions in South Korea as well as on a global scale [8].

According to Kim and Jeong [6], as the energy consumption by buildings in South Korea is rapidly increasing and because the building sector has shown outstanding potential in reducing its energy consumption, reducing GHG emissions in the sector should be a key measure of South Korea's national plan to reduce GHG emissions, overall. Although the South Korean government set an energy reduction target of $18.1 \%$, or 35.8 million ton $\mathrm{CO}_{2} \mathrm{eq}$, in business as usual (BAU) by 2030, it raised the target to $32.7 \%$ ( 64.5 million ton $\mathrm{CO}_{2} \mathrm{eq}$ ) in July 2018 [9]. To meet the revised goal, the government has established plans to strengthen policies regulating building permit standards for new buildings, to improve the energy efficiency in existing buildings, to promote the use of renewable energy and improve efficiency of building equipment, to develop infrastructure to share information about energy consumption in buildings, and to promote the improvement of energy consumption in buildings [9].

Basic research on reducing GHG emissions in South Korea's building sector has included two recent projects: (1) estimating emissions in buildings based on national statistics [6]; and (2) evaluating the potential of alternative scenarios to reduce emissions [8]. However, research on reducing GHG emissions remains insufficient. Thus, various studies are necessary to analyze the extent to which the mentioned policies have affected the reduction of emissions in South Korea's buildings.

This study aims to investigate the elements of building envelope design in a sample of office buildings for which construction permits have been acquired, and to analyze and compare their energy loads by the reference buildings modeled during the study. Based on the results of analysis, the effectiveness of the South Korean policy to reduce GHG emissions in the building sector has been evaluated. Moreover, this study also assesses whether the emissions reduction targets can be achieved by the deadline.

\subsection{Research Scope and Methods}

A sample of office buildings were categorized into two groups-Conventional (Group A) and new (Group B) - based on when building permits were issued (see Figure 1 and Section 3 for details). Furthermore, data regarding the three design elements (i.e., building form, window systems, and U-values of the performance of insulation in the envelope system (U-values)) in the buildings were gathered and subjected to statistical analysis. Here, U-value is a measure of reduction in heat loss (i.e., saving in energy) and mitigation in greenhouse gas emissions [10] (see Section 3.3 for details). The investigated and analyzed design elements of buildings were selected as design information (i.e., floor area, aspect ratio, number of floors, floor height, window systems, U-values, among others) at the time of building permit issuance, and all the investigated buildings were new construction. Furthermore, the results of statistical analysis revealed the development of reference building models for each building with calculable heating and cooling loads, which yielded eight building types with different combinations of the variable elements. In eight building-specific case studies, energy use in the buildings was analyzed, and each building's heating and cooling loads were calculated. Lastly, the results were analyzed to gauge the effects of South Korean policy to reduce GHG emissions in the building sector (see Figure 1). 


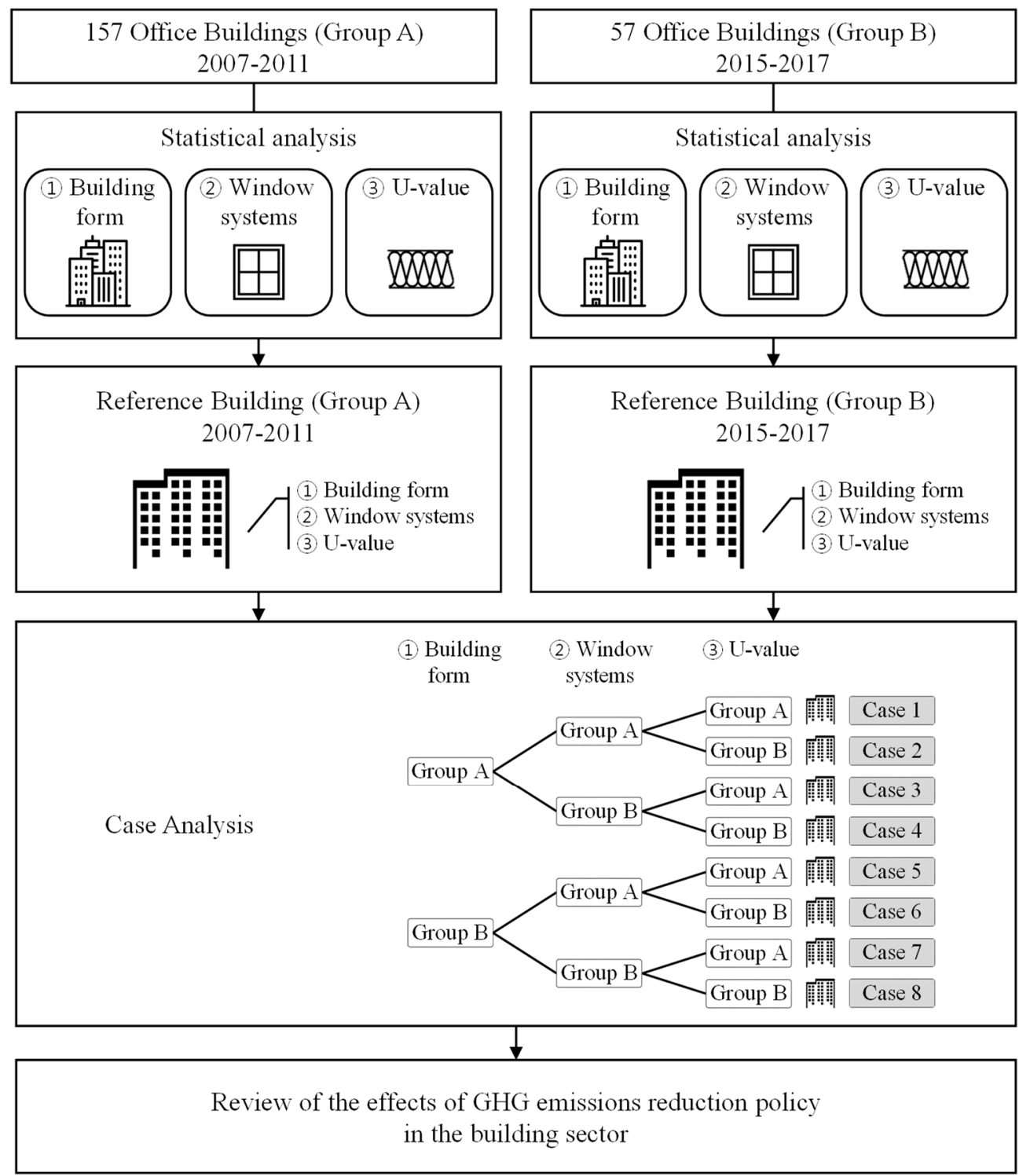

Figure 1. Research scope and methods of this study.

To limit the examination of the effects on South Korean policy to reduce GHG emissions in the building sector to the architectural elements of building design only, information about other elements, such as the heating, ventilation, and air-conditioning (HVAC) systems and a range of plant equipment were excluded from data collection. At the same time, to examine the effects of the policy from the perspective of policymakers and to increase the reliability of the results, reference buildings derived from statistical data representing numerous buildings were analyzed instead of specific buildings. The statistical data were reviewed by design professionals. Moreover, building energy simulation programs, namely EnergyPlus 8.9 [11] and OpenStudio 2.5 [12], which are commonly used to review alternative building designs and analyze energy consumption, have been used in this study.

\section{Related Works}

\subsection{Current State of Research on GHG Emissions in the Building Sector}

Kim and Jeong [6] used a GHG emissions estimation method that meets international standards and a database of statistics regarding energy consumption that lists monthly production and sales records of energy suppliers (i.e., national approval statistics) to calculate GHG emissions of buildings 
by year, energy source, and region. They observed that GHG emissions vary depending on different factors of GHG emissions caused by energy sources uses. Furthermore, they listed such uncertainty as a major limitation of their study. By contrast, using a Long-Range Energy Alternative Planning system, Jeong [8] proposed and analyzed scenarios for reducing GHG emissions in residential buildings. The result indicated a $12.9 \%$ reduction in GHG emissions by improving the energy efficiency of newly residential buildings under the influence of South Korean policy. In similar research conducted in China, Yu et al. [13] investigated the impact of building energy codes on energy consumption and $\mathrm{CO}_{2}$ emissions in the building sector by using a detailed building energy model. Their findings indicated that enforcing building energy codes can reduce energy consumption in China's buildings by $13-22 \%$. Moreover, Tan et al. [14] developed a model for analyzing trends in GHG emissions in China's building sector and analyzed the potential to reduce emissions by 2050. Among their results, the reduction of GHG emissions in the building sector had occurred slower than expected. Given that China's current policies are likely to be ineffective, they suggested that energy conservation policies for the construction of green buildings and the use of renewable energy as well as district heating should be promoted to reduce GHG emissions in the future. Emphasizing the importance of reducing GHG emissions in the building sector in order to achieve global targets for emissions reduction, Wang et al. [15] showed that to reduce the temperature by $1.5^{\circ} \mathrm{C}$ and $2{ }^{\circ} \mathrm{C}$ target from 2010 to 2050 in response to climate change, GHG emissions need to be reduced by $32 \mathrm{Gton} \mathrm{CO}_{2}$ and $60 \mathrm{Gton} \mathrm{CO}_{2}$, respectively, in the global building sector.

In addition, GHG emissions during the production, transportation, and construction of building materials and elements also forms a part of the non-negligible proportion of total GHG emissions [16,17]. Zhao et al. [18] estimated the lifecycle of GHG emissions from urban buildings and proposed potential effective measures for GHG emissions reduction. Previous researchers [17,19-21] have also focused on GHG emissions spanning the entire lifecycle of buildings. Moreover, many policies seek to reduce greenhouse gas emissions through energy savings at the operation phase [22].

The previous researches have reviewed the building sector's current and predicted future potential to reduce GHG emissions as well as the lifecycle of GHG emissions reduction and operation phase to reduce GHG; however, they have not examined the association between actual design trends in the building sector in light emission reduction policies. In particular, few studies have focused on the effect of reducing greenhouse gas emissions by concentrating on building envelopes. This study aims to conduct an interim check on the strengthen policies regulating building permit standards for new buildings currently being implemented by the Korean government.

\subsection{Purpose and Application of Reference Buildings}

Although reference buildings have been developed to assess current energy consumption and energy-saving measures, they can also be used to inform policy on reducing energy consumption and gauge the economic feasibility of implementing such policy in regions and individual countries worldwide.

In representative projects involving the identification of current energy consumption, TABULA [23] as well as ASIEPI [24] developed residential reference buildings in Europe, while Deru et al. [25] of the US Department of Energy developed reference buildings based on 16 building types in 16 locations throughout the United States. In South Korea, Kim et al. [26] modeled reference buildings for 11 building uses based on national statistics and with input data prepared by inversely calculating end-use energy use intensity from statistics. After comparing energy consumption in the reference buildings with that in actual buildings, the authors concluded that the reference buildings could be effectively used to inform national institutions and provide technological innovations for reducing GHG emissions.

In southern Brazil, Schaefer and Ghisi [27] developed reference buildings for single housing units by conducting a cluster analysis and subjecting the reference buildings to thermal and energy performance analyses. In Portugal, Brandão De Vasconcelos et al. [28] examined ways of optimizing 
the capacity of buildings' exterior walls to save energy based on 35,000 simulated scenarios using reference buildings of actual residential buildings. Meanwhile, in India, Bhatnagar et al. [29] developed reference buildings for high-rise and low-rise office buildings by collecting and processing data for 230 buildings during a 10-year period. In their analysis, cases were divided into four scenarios according to energy performance in terms of design standards for buildings in India.

Buso and Corgnati [30] proposed a method for modeling reference buildings on complex, multiuse buildings. They applied this method to Italian hotels in order to identify building materials that can support national energy and tourism policies. Brandão De Vasconcelos et al. [31] also developed reference buildings to make informed decisions on refurbishing buildings from technological as well as economic perspectives. They considered the incorporation of building orientation and discount rates in determining appropriate solutions for refurbishment.

Corgnati et al. [4] developed another set of reference buildings based on cost optimization to analyze energy performance in office buildings in Italy. Brandão De Vasconcelos et al. [32] defined reference buildings for residential buildings in Portugal using a cost optimization methodology in which building function, location, and construction period served as parameters.

$\mathrm{Li}$ et al. [33] developed a reference building to examine the refurbishment of low-carbon, high-rise residential buildings in Hong Kong, a city with a subtropical climate, and reviewed 88 options. Although reference models have also been used to evaluate the energy consumption of residential buildings $[34,35]$, they can additionally be applied to evaluate the energy consumption during the lifecycle of buildings [36], as well as for analyzing the geometry of energy models for urban buildings and cities, in general [37-39]. Reference buildings can also be used to inform the inspection and understanding of low-energy, low-carbon building technology in residential and non-residential buildings.

As demonstrated by previous studies, reference buildings have been developed for a variety of purposes in many countries around the world. In the study, reference buildings for office buildings were developed to calculate their energy loads according to three elements of building design — building form, window systems, and the performance of insulation in building envelope systems-in order to examine the effects of policies for reducing GHG emissions in new buildings in South Korea. In other words, reference buildings for office buildings were developed to calculate their energy loads according to three elements of building design in order to examine the effects of policies for reducing GHG emissions in new buildings.

\subsection{South Korea's Policy for Reducing GHG Emissions in the Building Sector}

\subsubsection{Progress Toward Meeting GHG Emissions Reduction Targets}

In 2009, the South Korean government set a national GHG emissions reduction target, which was $30 \%$ of BAU. It promised the international community that it would meet the target by 2020 . In follow-up policymaking, the government also enacted the Framework Act on Low Carbon Green Growth in 2010 and, in 2014, established a road map for achieving the national target for GHG emissions with year-by-year implementation plans for various sectors of the economy (Korean Government, 2014). As shown in Table 1, the building sector plan divides the sector into residential and commercial subsectors, with reduction rates set at $27.0 \%$ and $26.7 \%$, respectively, compared to BAU for 2020 [40].

Table 1. 2014 plan for the building sector with reduction target compared to business as usual (BAU) for 2020 [40].

\begin{tabular}{ccccc}
\hline \multirow{2}{*}{ Sector } & \multirow{2}{*}{$\begin{array}{c}\text { 2020 BAU } \\
\left.\text { (Million Ton } \mathbf{C O}_{\mathbf{2}} \mathbf{e q}\right)\end{array}$} & \multicolumn{2}{c}{ Reduction Target for 2020 (Million Ton $\mathrm{CO}_{\mathbf{2}} \mathbf{e q )}$} \\
\cline { 3 - 4 } & 81.2 & Reduction & Targeted Emission & Rate of Reduction (\%) \\
\hline Residential & 86.4 & 21.9 & 59.2 & 27.0 \\
Commercial & 167.6 & 45.1 & 63.4 & 26.7 \\
Total & & 122.6 & 26.9 \\
\hline
\end{tabular}


In response to new shifts in climatic regimes of South Korea, in 2015, the South Korean government submitted its intended nationally determined contribution to the United Nations. It contained a plan to reduce GHG emissions by 37\%, including its overseas ventures, in light of BAU for 2030. In addition, following the Paris Agreement in 2015, the South Korean government revised the Enforcement Decree of the Framework Act on Low Carbon Green Growth and established another roadmap for achieving newly set national targets for reduced GHG emissions for 2030. Another roadmap was announced in 2018 when it became clear that a plan was needed to clearly and specifically prompt the implementation of means to reduce emissions, to reflect changes in national policies regarding measures to reduce energy and fine dust in the air, and to foster accountability by developing policy in light of suggestions and criticism from both the domestic and international communities [9]. Based on these considerations, the latest roadmap maintains the 37\% reduction target against BAU, as shown in Figure 2 [9], that is to increase the reduction in the amount of GHG emissions in South Korea from 25.7\% to 32.5\% and to reduce the remaining $4.5 \%$ in overseas and forest sink activities.

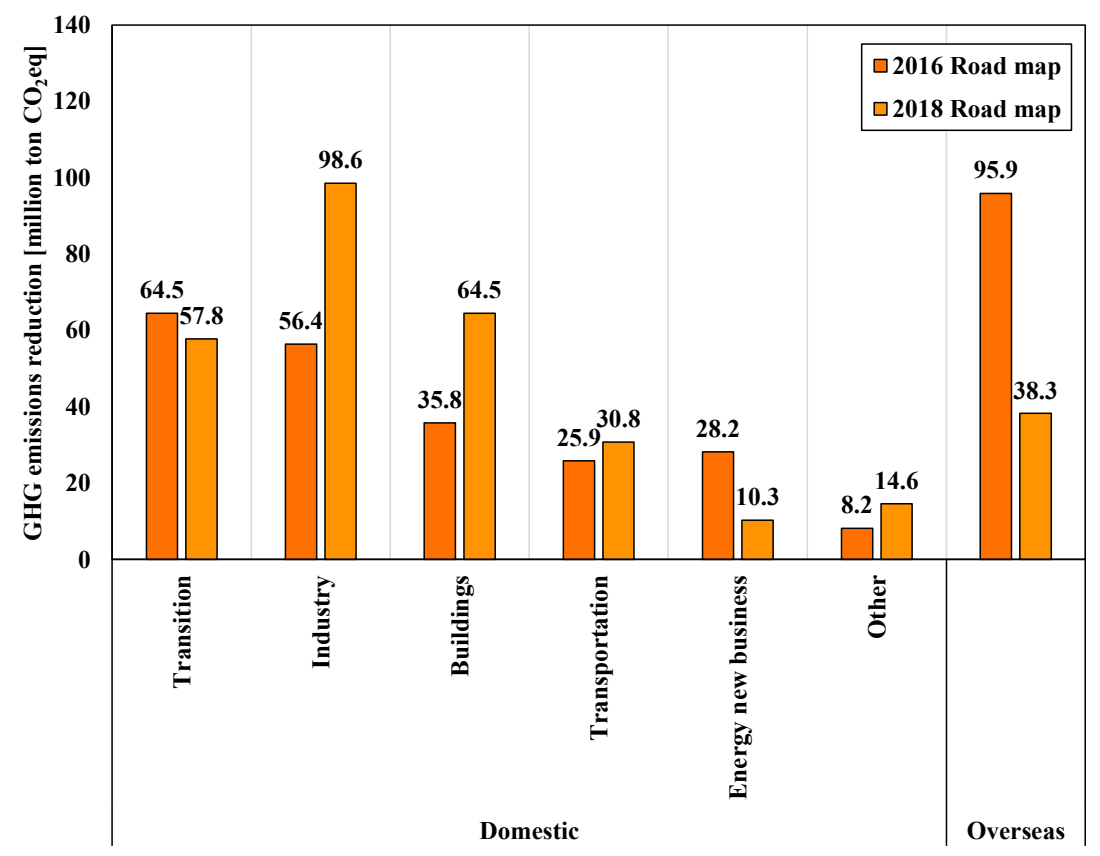

Figure 2. Comparison of revised roadmaps to achieve targeted reductions in GHG emissions by 2030 [9].

Table 2 allows a comparison of the various targets for reduced GHG emissions in South Korea. Although the rate of reduction in the building sector was initially set at $18.1 \%$, the revised roadmap adjusted that rate to $32.7 \%$, largely to accommodate adjustments to BAU (i.e., 28.5 million ton $\mathrm{CO}_{2} \mathrm{eq}$ ) in response to Gross Domestic Product (GDP), population, energy prices, and past emissions trends [9].

Table 2. Comparison of the various targets for reduced GHG emissions in South Korean building sector [9].

\begin{tabular}{ccccc}
\hline \multirow{2}{*}{ Roadmap } & $\begin{array}{c}\text { 2030 BAU } \\
\text { (Million Ton } \mathrm{CO}_{\mathbf{2}} \text { eq) }\end{array}$ & \multicolumn{3}{c}{ Building sector (Million Ton $\mathrm{CO}_{\mathbf{2}}$ eq) } \\
\cline { 3 - 5 } & 197.2 & Reduction & Targeted Emission & Rate of Reduction (\%) \\
\hline $\begin{array}{c}\text { 2016 Roadmap (i.e., } \\
\text { pre-amendment) }\end{array}$ & & 35.8 & 161.4 & 18.1 \\
\cline { 3 - 5 } $\begin{array}{c}\text { 2018 Roadmap (i.e., } \\
\text { post-amendment) }\end{array}$ & & 64.5 & 132.7 & 32.7 \\
\hline
\end{tabular}




\subsubsection{Major Strategies to Reduce GHG Emissions in the Building Sector}

To achieve the target for reduced GHG emissions in the building sector set for 2030 by the revised roadmap [9], four major policy measures have been proposed. First, to set a reduction target of 5.5 million ton $\mathrm{CO}_{2}$ eq against BAU in the building sector by 2030, four policies have been prepared to significantly reduce the emissions of new buildings. Second, for existing buildings, five policies will be implemented to achieve a reduction target of 9.6 million ton $\mathrm{CO}_{2} \mathrm{eq}$ against $\mathrm{BAU}$ in the building sector by 2030 . Third, to promote the use of renewable energy and the efficiency of building equipment, three policies will be implemented to achieve a reduction target of 15.2 million ton $\mathrm{CO}_{2}$ eq against BAU in the building sector. Lastly, regarding the development of infrastructure to share information about buildings' energy use and promote the improvement of energy consumption, four policies will be implemented to meet a reduction target of 5.8 million ton $\mathrm{CO}_{2}$ eq against $\mathrm{BAU}$ in the building sector, also by 2030. A total of 64.5 million ton $\mathrm{CO}_{2} \mathrm{eq}(32.7 \%)$ is planned to be reduced by combining all of these measures to accommodate the adjusted BAU (i.e., 28.5 million ton $\mathrm{CO}_{2} \mathrm{eq}$ ).

\section{Investigating and Analyzing Office Buildings Using Design Data}

To obtain the sample for the study, the design data of target office buildings were collected in the form of drawings and construction permit records and analyzed. For Group A, 157 buildings designed in South Korea from 2007 to 2011 were selected to represent office buildings designed using conventional methods. For Group B, 57 buildings constructed from 2015 to 2017 were included to represent office buildings designed by using new design methods and technologies. At the Copenhagen climate change conference in 2009, the South Korean government announced that its goal is to reduce the country's $\mathrm{CO}_{2}$ emissions by up to $30 \%$ below the BAU projections by 2020, with the base year being 2007 [8,41,42]. Furthermore, at the 21st Conference of Parties (COP21) in 2015, it declared the establishment of a plan to reduce $\mathrm{CO}_{2}$ emissions by $37 \%$ by 2030, by assuming 2015 as the base year [8,9]. Thus, in this study, Group A constituted new buildings from 2007 to 2011, and Group B constituted new buildings from 2015 to 2017. Figure 3 illustrates the distribution of the office buildings by year. Three characteristic elements of the design of the buildings—building form, window systems, and U-values-were analyzed, as detailed in the following subsections.

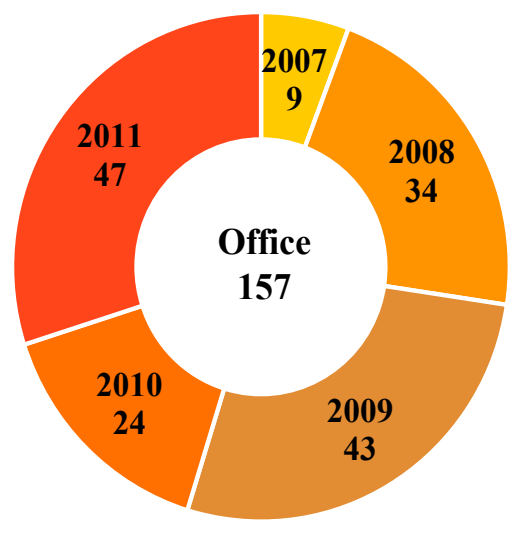

(a)

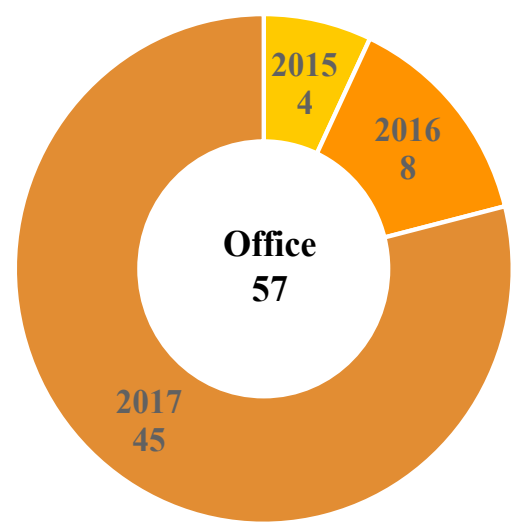

(b)

Figure 3. Distribution of office buildings by year into (a) Group A; and (b) Group B.

\subsection{Building Form}

To determine the building form, elements of design that directly affected a building's appearance were investigated, namely floor area, aspect ratio, number of floors, and floor height. 


\subsubsection{Total Floor Area}

Figure 4a shows the distribution of the total floor areas of buildings in Group A. The maximum and minimum values were $336,026 \mathrm{~m}^{2}$ and $885 \mathrm{~m}^{2}$, respectively, while the mean and median values were $27,679 \mathrm{~m}^{2}$ and $13,124 \mathrm{~m}^{2}$, respectively. By contrast, Figure $4 \mathrm{~b}$ depicts the distribution of total floor areas of the buildings in Group B; their maximum and minimum values were 292,078 $\mathrm{m}^{2}$ and $283 \mathrm{~m}^{2}$, respectively, while their mean and median values were $22,823 \mathrm{~m}^{2}$ and $7728 \mathrm{~m}^{2}$, respectively. Mean values were applied in developing the reference building models used in the case studies.

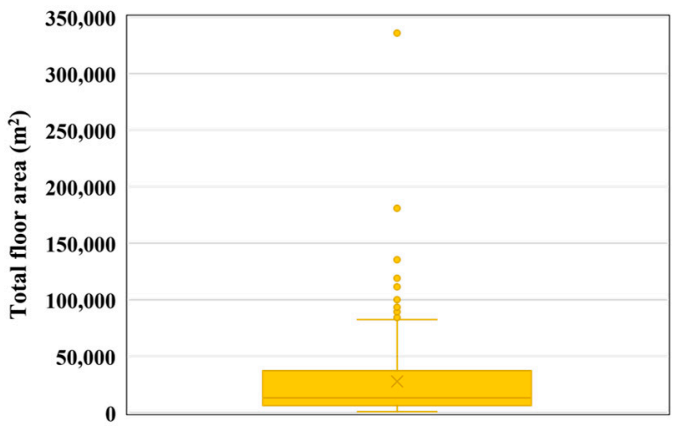

(a)

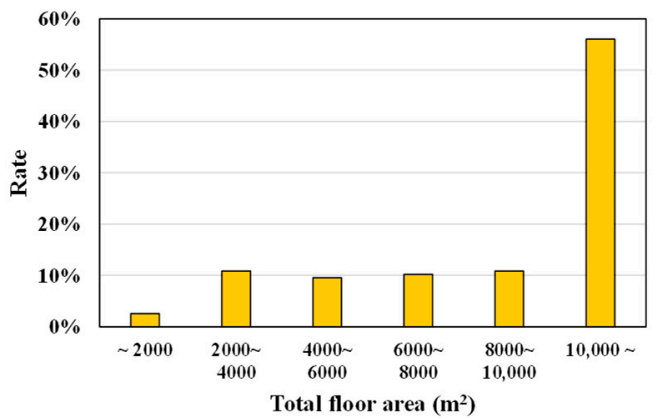

(c)

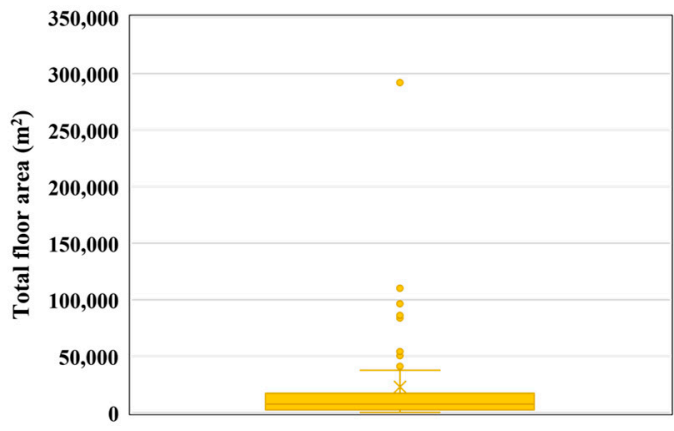

(b)

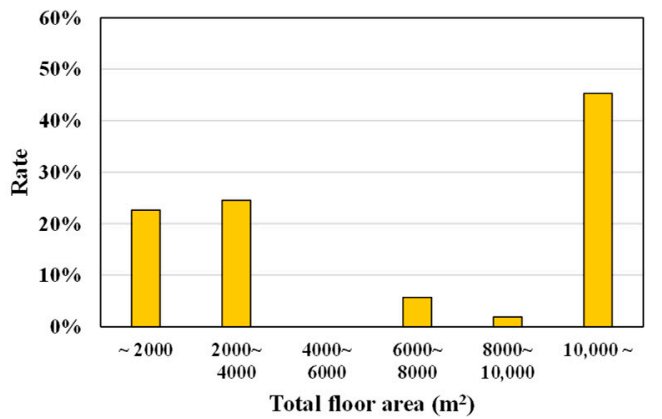

(d)

Figure 4. Distribution of total floor area. (a) Group A; (b) Group B; (c) Distribution ratios in Group A; and (d) Distribution ratios in Group B.

The two groups were sub-divided into six groups by total floor area, the distribution ratios of which appear in Figure 4c,d. The floor area distribution of Group A was within the medium-to-large range of $10,000 \mathrm{~m}^{2}$ or greater, which represented $56 \%$ of all buildings surveyed. By contrast, Group B demonstrated a wider distribution, some even within the range of small buildings with total floor areas of less than $4000 \mathrm{~m}^{2}$, which represented $48 \%$ of the total buildings surveyed. However, the highest ratio in Group B also fell within the range of total floor area of $10,000 \mathrm{~m}^{2}$ or greater, which represented $45 \%$ of the total buildings surveyed.

\subsubsection{Aspect Ratios of Building Plans}

Figure 5 illustrates the distribution of aspect ratios of building plans. As shown in Figure 5a, in Group A, the maximum value was 6.30:1, the minimum value was 1.01:1, the mean value was 2.17:1, and the median value was 1.54:1. In Group B, as shown in Figure 5b, the maximum value was 6.70:1, the minimum value was 1.03:1, the mean value was 2.43:1, and the median value was 1.91:1. Taken together, higher ratios in Group B than in Group A indicate that the buildings in Group B were more elongated. 


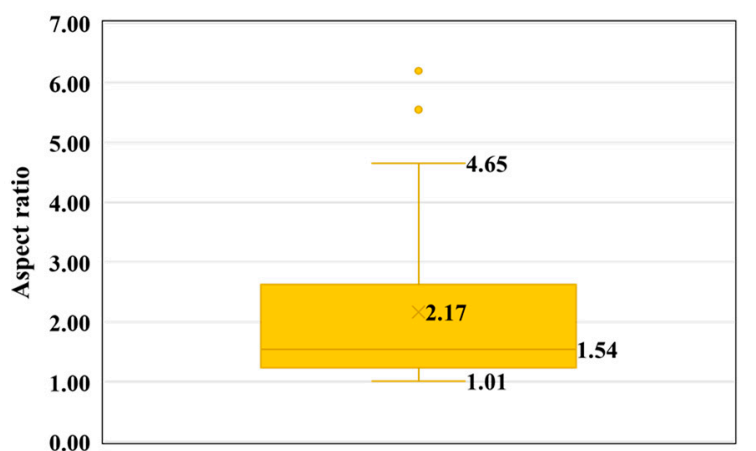

(a)

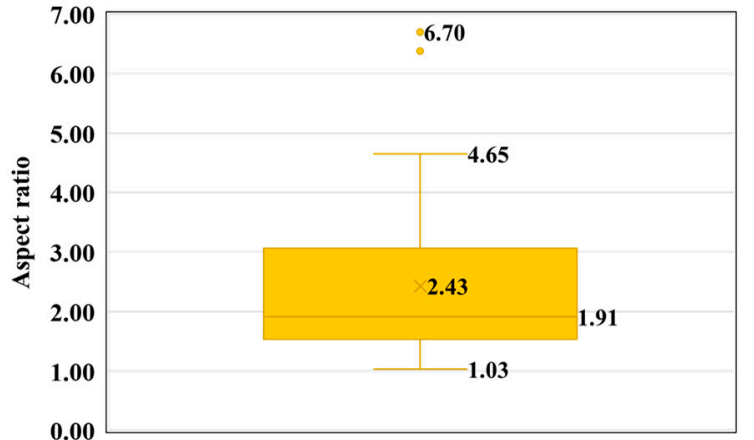

(b)

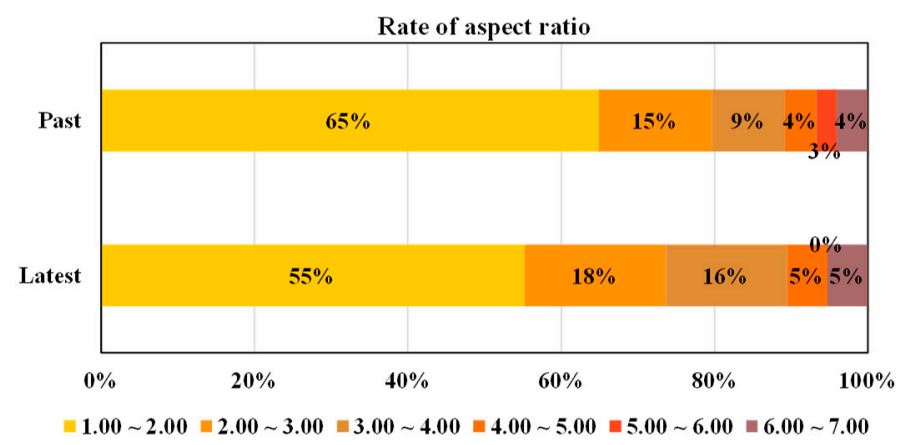

(c)

Figure 5. Distribution of aspect ratios of building plans. (a) Group A; (b) Group B; and (c) Distribution ratio of the aspect ratio in Groups A and B combined.

The distribution ratios of the aspect ratios in the two groups appear in Figure $5 \mathrm{c}$. In both groups, the most frequent distributions were in the range of 1.0-2.0, with a distribution of $65 \%$ in Group A and $55 \%$ in Group B. Moreover, the distribution ratio tended to decrease as the aspect ratio increased. Overall, Group B demonstrated a greater increase than Group A.

\subsubsection{Number of Floors}

Figure 6 presents the distribution of the number of floors in the buildings surveyed. Buildings in Group A had a range of 1-63 floors, as shown in Figure 6a; the mean and median values of the number of floors were 10 and 8, respectively. As shown in Figure 6b, the number of floors in buildings in Group $B$ varied from low to exceptionally high; the mean and median values of the number of floors were 12 and 9, respectively. The distribution ratios of the number of floors in buildings in the sample is shown in Figure 6c. In Group A, 39\% of buildings had fewer than five stories, 43\% had 5-15 stories, and $18 \%$ had 15 stories or more. In Group B, 30\% of buildings had fewer than five stories, $53 \%$ had $5-15$ stories, and $17 \%$ had 15 stories or more. The mean and median values of the two groups were the most frequently distributed segments, that is, $5-15$ stories.

\subsubsection{Floor Height}

Figure 7 illustrates the distribution of floor height in the buildings surveyed. In Group A, buildings typically had floor heights distributed in the range of 3.0-6.0 m, as shown in Figure 7a, with a mean as well as median value of $4.0 \mathrm{~m}$. In Group B, buildings had floor heights distributed in the range of 2.7-12.2 m, as shown in Figure $7 \mathrm{~b}$, with a mean as well as median value of $3.9 \mathrm{~m}$, that is, $0.1 \mathrm{~m}$ less than that of buildings in Group A. 


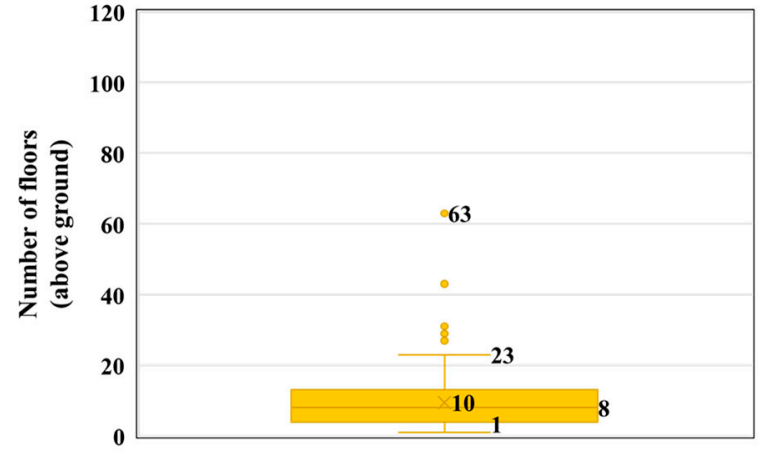

(a)

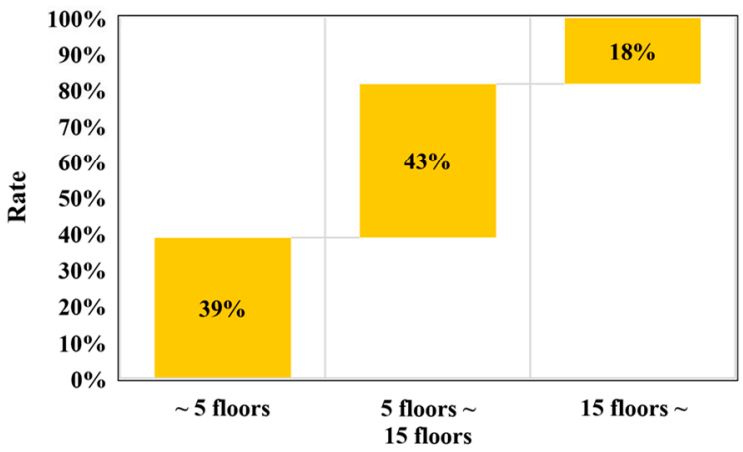

(c)

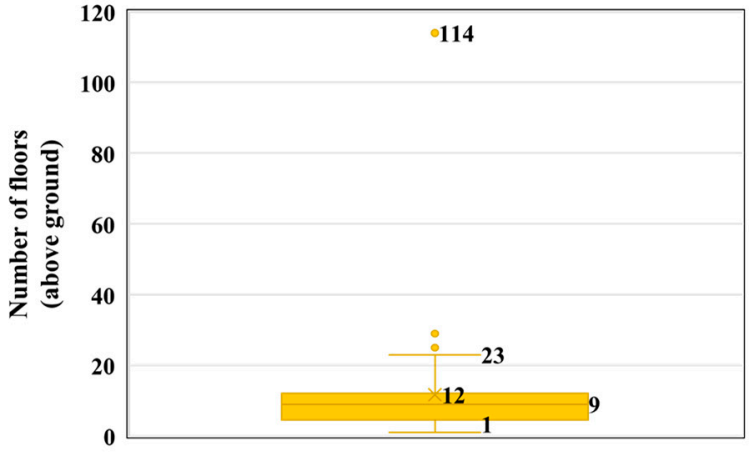

(b)

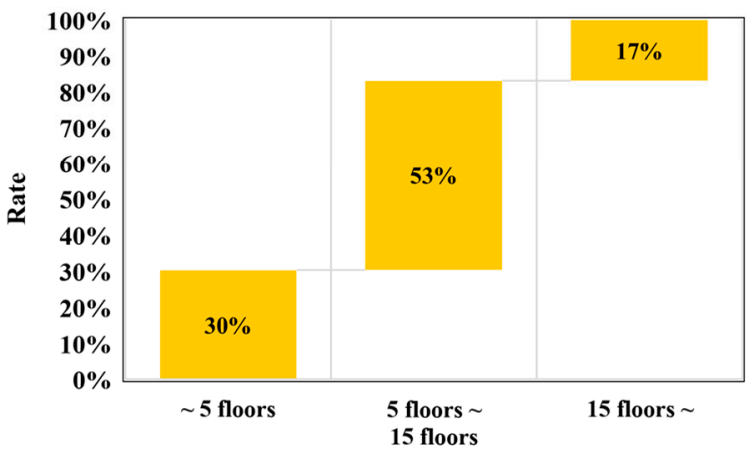

(d)

Figure 6. Distribution of the number of floors in (a) Group A; (b) Group B; and Distribution ratios of number of floors in Groups A (c) and B (d) combined.

Floor height was scaled according to the uses of the interior space and greatly reflected elements of design. In addition to capturing necessary workspace, floor height considered the ceiling plenum that housed items, such as lighting equipment and HVAC ducts as well as provided access to underfloor air distribution systems. Floor height is an important factor to consider in designing buildings in light of heating and cooling loads (e.g., selection of HVAC systems) and their capacity to accommodate internal heating requirements. As buildings in the sample corroborate, floor height has been more diversely designed in recent years than in years prior due to efforts to permit various interior uses and functions.

\subsection{Window Systems}

Figure 8 depicts the distribution of window systems in the two groups. In Group A, $45.2 \%$ of buildings used a low- $\varepsilon$ (low emissivity) glass coating system, whereas clear glass accounted for more than half of all glass in the group buildings in Figure 8a. However, in Group B, 81.0\% of buildings used a low- $\varepsilon$ glass coating system, whereas clear glass was used in only $19 \%$ of the buildings in Figure 8 b. Coating the pane surfaces with low emissivity materials is an effective solution to reduce heat transfer by radiation. For instance, for air-filled double pane window having a gap width of $6 \mathrm{~mm}$, the U-value decreases about $32 \%$ when emissivity is decreased from 1 to 0 [43]. In terms of glazing composition, 24-mm-thick double-glazed systems were the most common with both low- $\varepsilon$ glass and other types of glass in Group A; in Group B, by contrast, low- $\varepsilon$ glass was used in a variety of glass systems with glass of varying thickness-for example, in 28-mm-thick double- or quadruple-glazed systems. For clear glass, although double-glazed systems were prevalent in Group A, quadruple-glazed systems were also common. 


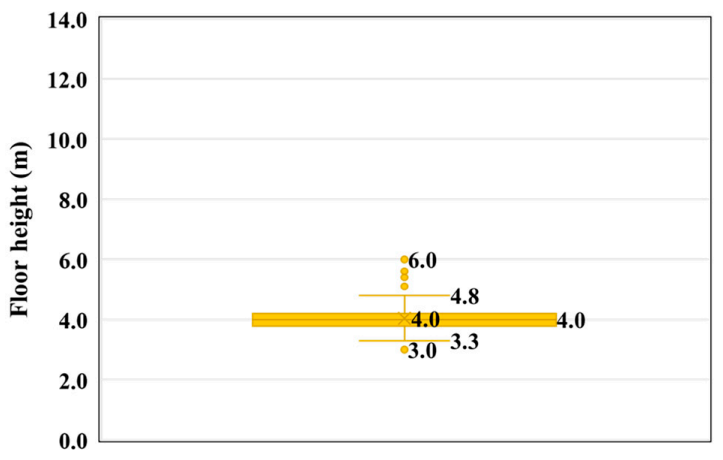

(a)

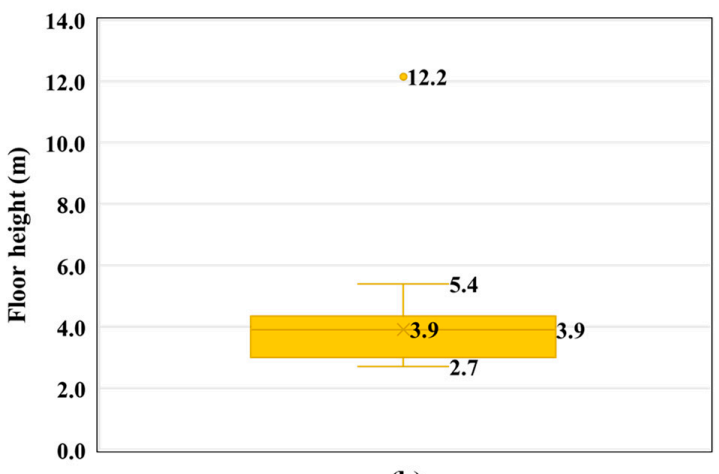

(b)

Figure 7. Distribution of the floor height. (a) Group A; and (b) Group B.

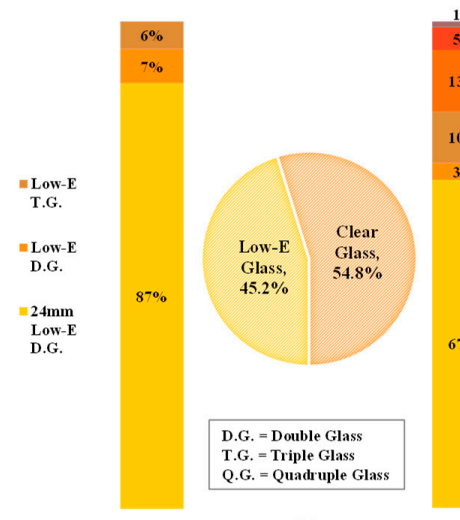

(a)

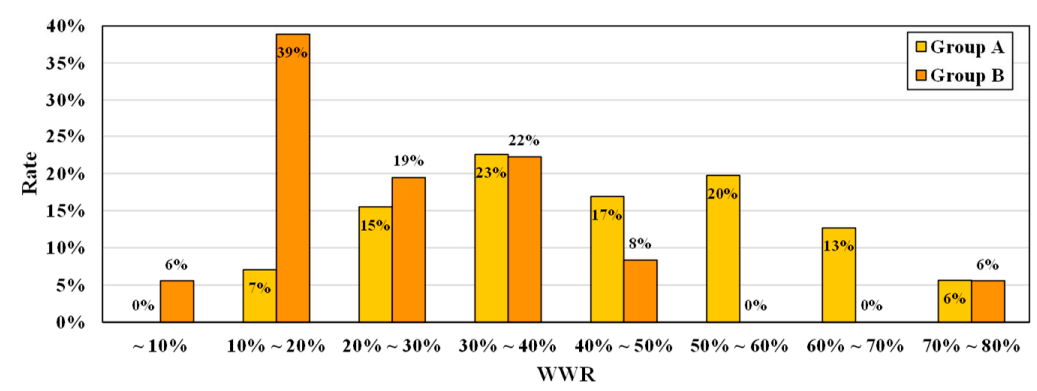

(c)

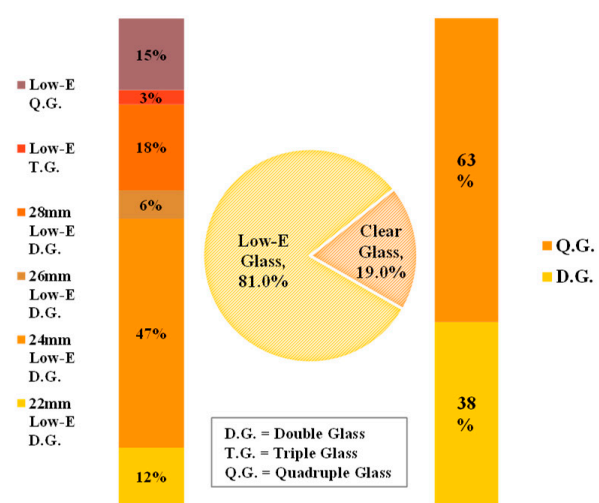

(b)

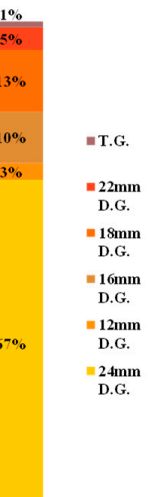

- T.G.

D.G.

D.G.

$16 \mathrm{~mm}$

$12 \mathrm{~mm}$

$24 \mathrm{~mm}$
D.G.

Figure 8. Distribution of the window systems. (a) Group A; (b) Group B; and (c) Distribution ratio of window-to-wall ratios (WWR) by segment in Groups A and B in comparison.

Figure $8 \mathrm{c}$ shows the distribution of window-to-wall ratios (WWR) in the two groups. In Group A, the distribution of ratios exceeded the range of $30-60 \%$, whereas in Group B, the distribution of ratios peaked at about $40 \%$ and fell within the range of $10-20 \%$. 


\subsection{U-Values}

U-value is a term in building science, which is a measure of heat loss in a building element such as a wall, floor, roof or window. In other words, $U$-value is defined as being reciprocal of all the thermal resistances in the building element. U-value is also referred to as "overall heat transfer coefficient" and measures how well components of a building envelope transfer heat. U-value assessment is very useful since it allows predicting the composite behaviour of an entire building element rather than relying on the properties of individual materials [10].

In the two groups, the distribution of U-values was determined in four parts of each building envelope: The exterior wall, the roof, the lowest floor, and windows, as shown in Figure 9. In Group A, mean U-values were $0.393 \mathrm{~W} / \mathrm{m}^{2} \cdot \mathrm{K}$ at the exterior wall, $0.215 \mathrm{~W} / \mathrm{m}^{2} \cdot \mathrm{K}$ at the roof, $0.311 \mathrm{~W} / \mathrm{m}^{2} \cdot \mathrm{K}$ at the lowest floor, and $2.478 \mathrm{~W} / \mathrm{m}^{2} \cdot \mathrm{K}$ at windows, as shown in Figure 9a. In Group B, as shown in Figure 9b, mean U-values were $0.240 \mathrm{~W} / \mathrm{m}^{2} \mathrm{~K}$ at the exterior wall, $0.138 \mathrm{~W} / \mathrm{m}^{2} \cdot \mathrm{K}$ at the roof, $0.193 \mathrm{~W} / \mathrm{m}^{2} \cdot \mathrm{K}$ at the lowest floor, and $1.403 \mathrm{~W} / \mathrm{m}^{2} \cdot \mathrm{K}$ at windows. The U-values were lower in Group B than in Group A at all four parts, which clearly confirms the superior insulation performance of buildings in Group B, especially at their windows, partly due to changes in design that have strengthened the insulation performance of newly constructed buildings in response to national policy for reducing GHG emissions.

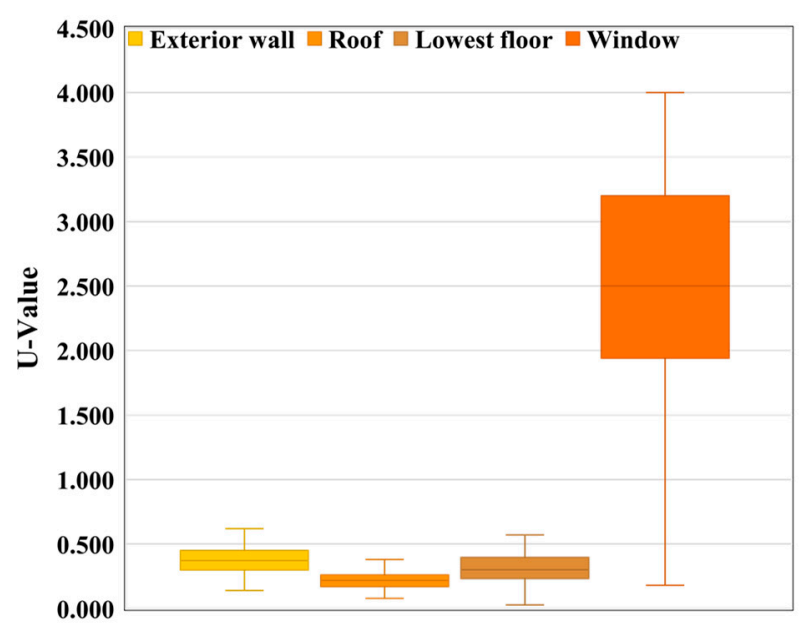

(a)

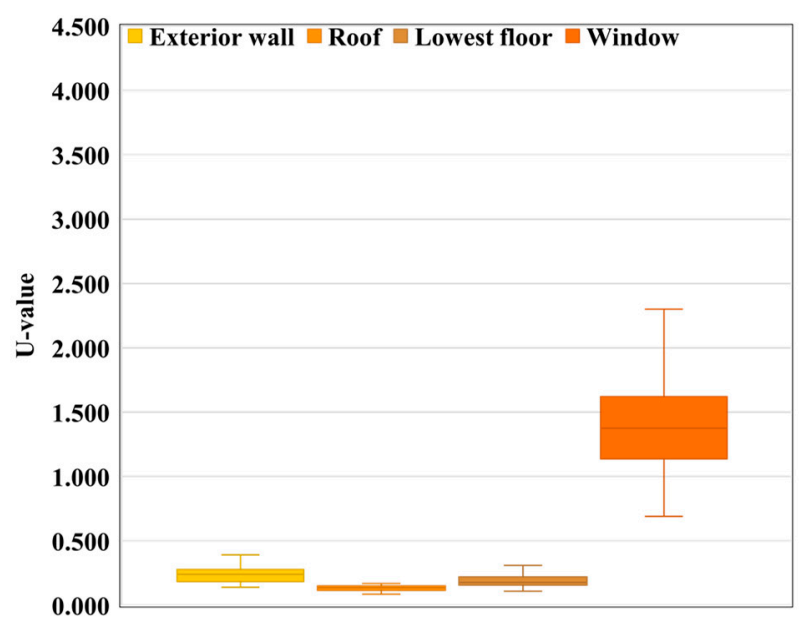

(b)

Figure 9. Distribution of the U-values. (a) Group A; and (b) Group B. 
The type of insulation used for each of the four parts appears in Figure 10. In the exterior walls of buildings in Group A, extruded polystyrene form insulation (XPS) was the most frequently used type (i.e., approx. $40 \%$ ), followed by glass wool, expanded polystyrene (EPS), and expendable polystyrene beads, as shown in Figure 10a. However, in Group B, EPS was the most widely used type, and XPS remained common while the use of rigid polyurethane (PUR) and polyisocyanurate (PIR) foams had increased.

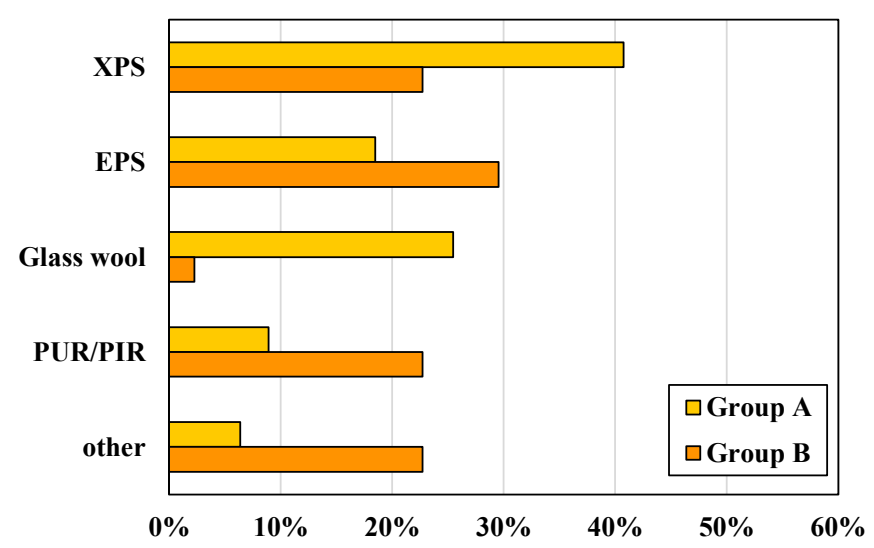

(a)

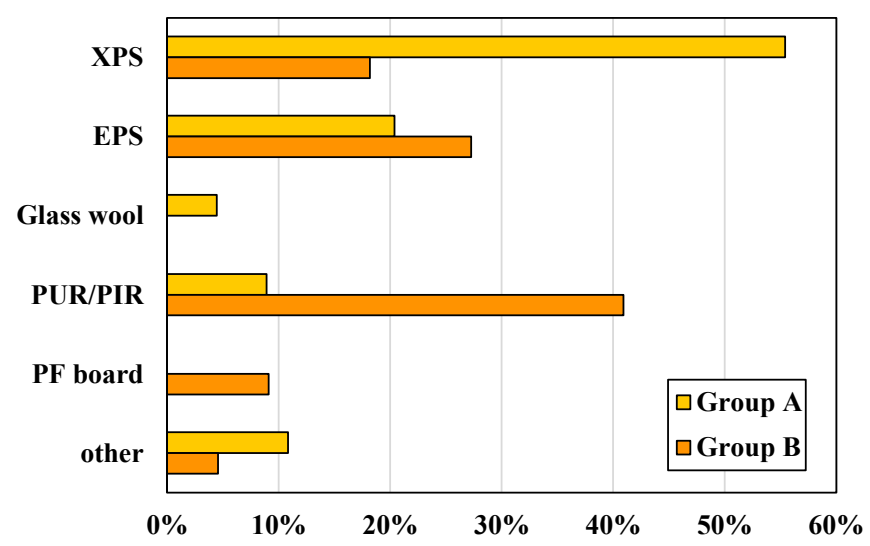

(b)

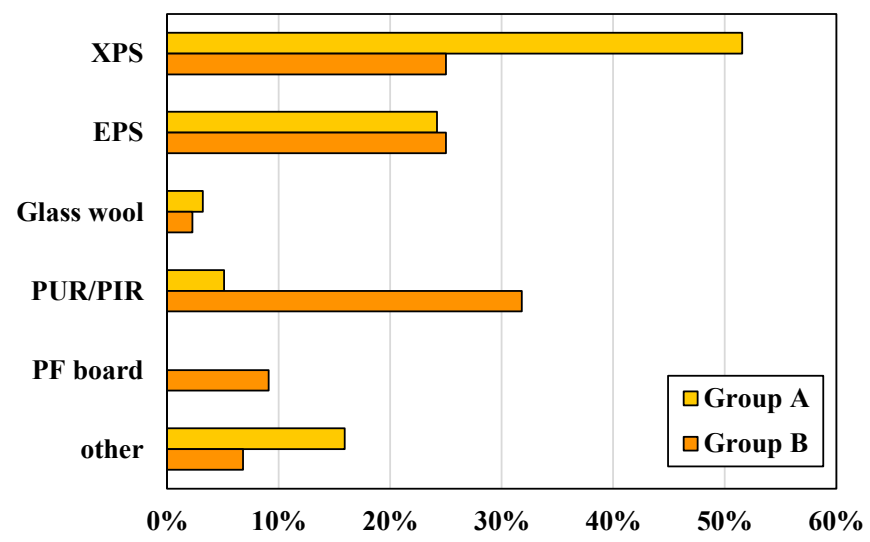

(c)

Figure 10. Distribution of the insulation in Groups A and B. (a) Exterior wall; (b) Roof; and (c) Lowest floor. (Extruded Polystyrene Form Insulation (XPS); Expendable Polystyrene (EPS); Polyurethane/ Polyisocyanurate (PUR/PIR); Phenolic Foam board). 
For roofs, as with exterior walls, XPS was the most frequent type of insulation in buildings in Group A, while its use was far less in Group B. Instead, the use of PUR/PIR in buildings in Group B indicated an increase of approximately $32 \% p$, while the use of EPS increased by about $7 \% p$. On the lowest floors, more than $52 \%$ of buildings in Group A used XPS, whereas only $25 \%$ of buildings in Group B used it, as shown in Figure 10c. As with roofs, the lowest floors also showed an increase in the use of PUR and PIR by about $27 \% p$.

Changes in U-values, which indicate the performance of insulation in a building's envelope, confirm that the values for each four parts of buildings in the sample have been appropriately strengthened to keep pace with the improved performance of insulation afforded by energy-saving building designs. Among the types of insulation used, XPS, which was the most frequently used in Group A, decreased in all parts of the building envelope, whereas the use of PUR/PIR increased. The use of EPS was similar in both groups of buildings but slightly higher in Group B. Results of the analysis reveal that in South Korea, glass wool is preferred to plastic insulation. Thus, the insulation material used to ensure the insulating capacity of a building envelope is an important factor in the passive energy performance of buildings. At the same time, the choice of insulation material is affected by country-specific criteria for designing insulation, the current market status of materials, and the cost of the product and its installation.

\section{Case Study}

\subsection{Reference Buildings and Factors of Building Design}

In this study, three design elements (building form, window systems, U-values) were investigated and analyzed to review the policies related to the envelope of new buildings. Therefore, a total of eight cases were used to compare and examine three design elements of the two groups (i.e., Group A and B). A case study was performed on each reference building, which was developed according to results of the analysis of data representing three elements of building design. Details of the three elements in the reference buildings were finalized following their review by design professionals (see Table 3). After eight reference buildings were simulated with various combinations of those elements (see Table 4 and Figure 1), the building load (cooling and heating) of each building was simulated and analyzed.

Table 3. Detail of the design elements in the reference building.

\begin{tabular}{cccc}
\hline & Categories & Group A & Group B \\
\hline \multirow{4}{*}{ Building form } & Total floor area $\left(\mathrm{m}^{2}\right)$ & 27,679 & 22,823 \\
& Aspect ratio & $2.17: 1$ & $2.43: 1$ \\
& Number of stories (above ground) & 10 & 12 \\
& Number of stories (below ground) & 2 & 2 \\
& Floor height (m) & 4.0 & 3.9 \\
\hline \multirow{2}{*}{ Window systems } & WWR $(\%)$ & 45 & 27 \\
& Window filling gas & Air & Argon ${ }^{1}$ \\
\hline \multirow{2}{*}{ U-values } & Exterior wall $\left(\mathrm{W} / \mathrm{m}^{2} \cdot \mathrm{K}\right)$ & 0.393 & 0.240 \\
& Roof $\left(\mathrm{W} / \mathrm{m}^{2} \cdot \mathrm{K}\right)$ & 0.215 & 0.138 \\
& Lowest floor $\left(\mathrm{W} / \mathrm{m}^{2} \cdot \mathrm{K}\right)$ & 0.311 & 0.193 \\
& Window $\left(\mathrm{W} / \mathrm{m}^{2} \cdot \mathrm{K}\right)$ & 2.478 & 1.403
\end{tabular}

\footnotetext{
${ }^{1}$ Filling the window cavity with low conductive gases such as argon and krypton instead of air is beneficial to reduce heat transfer by conduction and convection [44]. The U-value is decreased between $5 \%$ and $20 \%$ depending on emissivity if argon is used instead of air. The benefit of using argon is more apparent for windows coated with low emissivity materials since the ratio of heat transfer by gaseous conduction and convection to radiative heat transfer is relatively higher [43].
} 
Table 4. Composition of the eight case models.

\begin{tabular}{cccc}
\hline Categories & Building Form & Window Systems & U-Values \\
\hline Case 1 (reference building of Group A) & Group A & Group A & Group A \\
\hline Case 2 & Group A & Group A & Group B \\
Case 3 & Group A & Group B & Group A \\
Case 4 & Group A & Group B & Group B \\
Case 5 & Group B & Group A & Group A \\
Case 6 & Group B & Group A & Group B \\
Case 7 & Group B & Group B & Group A \\
\hline Case 8 (reference building of Group B) & Group B & Group B & Group B \\
\hline
\end{tabular}

Of the reference buildings, Case 1 was developed by applying the characteristics of Group A to all three elements. The effects of the three elements were analyzed individually in a stepwise process by first comparing Case 1 with Cases 2, 3, and 5, followed by Cases 4, 6, and 7. Last, by comparing Case 1 with Case 8 of Group B, the cooling and heating loads and the energy reduction ratio were analyzed in consideration of changes to building design. Based on this analysis, the effects of South Korea's policies for reducing GHG emissions in newly constructed buildings were assessed.

\subsection{Reference Building for Case Study}

Prior to building simulation, four of the eight reference buildings were modeled with different combinations of building forms and window systems, as shown in Figure 11. All U-values representing groups A and B were subsequently applied to each of the four reference buildings, which produced the eight cases.

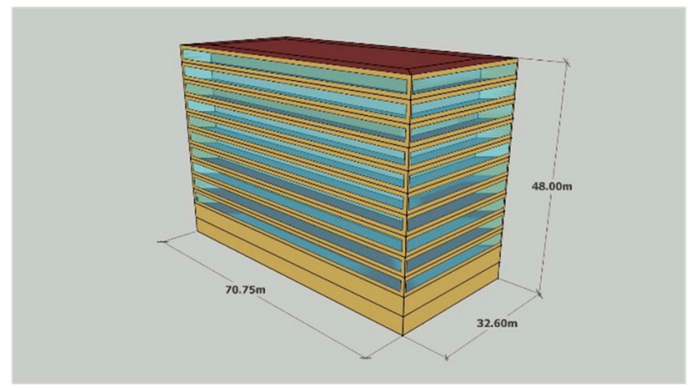

(a)

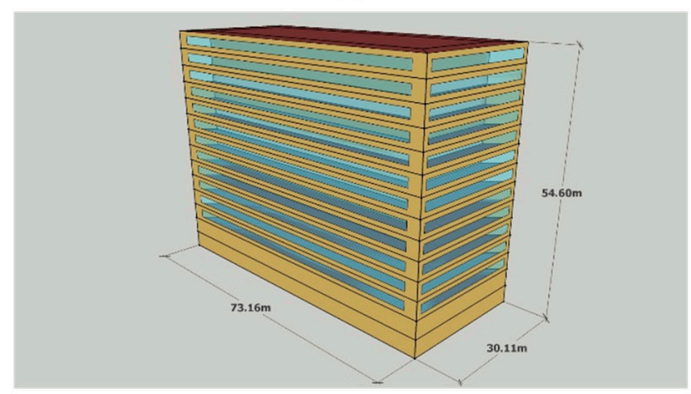

(c)

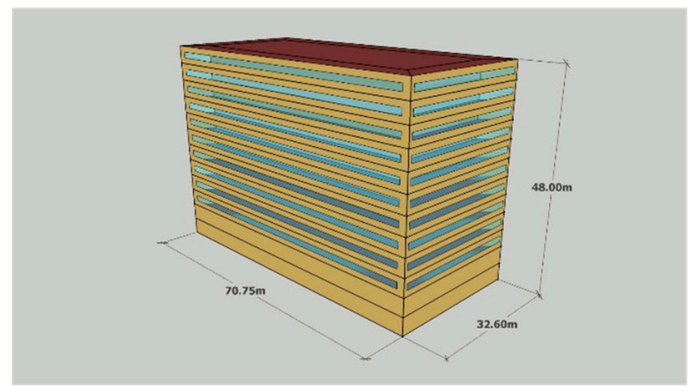

(b)

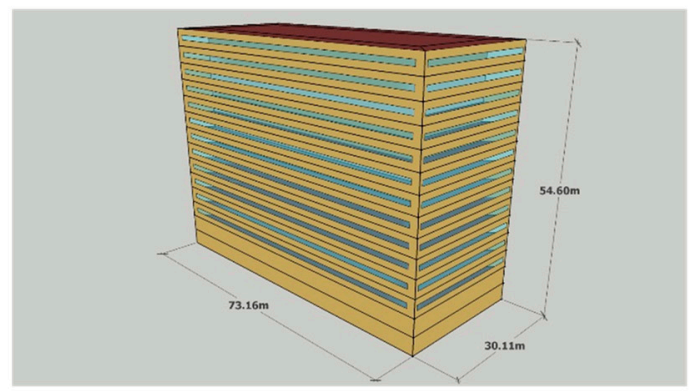

(d)

Figure 11. Reference buildings for case studies: (a) Cases 1 and 2; (b) Cases 3 and 4; (c) Cases 5 and 6; and (d) Cases 7 and 8 .

\subsection{Results of Simulations of the Reference Buildings}

To limit the study's attention to the individual influence of elements of the architectural design of the reference buildings, internal thermal load density and the schedule of indoor environments were set such that they were the same for all cases, whereas heating and cooling loads were calculated using 
the IdealLoadAirSystem of the EnergyPlus simulation tool. IdealLoadAirSystem is used in situations where the user wishes to study the performance of a building without modeling a full HVAC system [45]. The IdealLoadAirSystem is an object defined to supply heating and cooling to a zone to meet any heating or cooling demand of the zone at all times with $100 \%$ efficiency. The IdealLoadAirSystem is widely used to investigate geometry in the early stages of the building design, to study and test complex building materials, and to optimize building envelope performance [46,47]. In this study, the IdealLoadAirSystem was applied to evaluate the building envelope performance. The results of the analysis for the eight cases appear in Figure 12. To quantify the effects of changes in the three elements on cooling and heating loads, all results were analyzed based on the reference building representing Group A (Case 1), the results of which appear in Table 5.

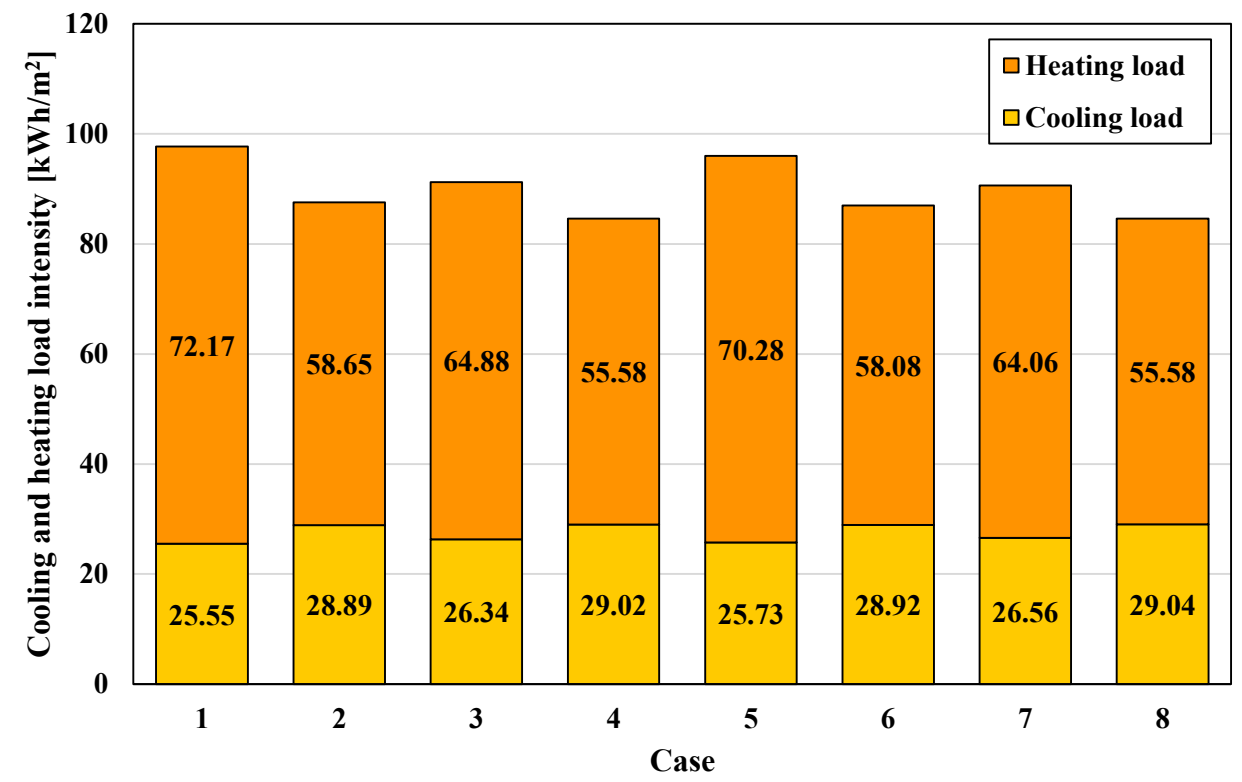

Figure 12. Cooling and heating load intensities in the eight cases.

Table 5. Summary of the eight cases.

\begin{tabular}{|c|c|c|c|c|c|}
\hline & \multirow{2}{*}{ Division } & \multirow{2}{*}{ Comparison } & \multicolumn{3}{|c|}{ Building Load Variation $\left(\mathrm{kWh} / \mathrm{m}^{2}\right)$} \\
\hline & & & Cooling & Heating & Total \\
\hline (1) & Building form (F) & Case 1 vs. Case 5 & 0.18 & -1.89 & -1.71 \\
\hline (2) & Window system $(\mathrm{W})$ & Case 1 vs. Case 3 & 64.5 & 132.7 & 32.7 \\
\hline (3) & U-value $(\mathrm{U})$ & Case 1 vs. Case 2 & 3.34 & -13.52 & -10.18 \\
\hline (4) & F \& W & Case 1 vs. Case 7 & 1.01 & -8.11 & -7.10 \\
\hline (4) ${ }^{\prime}$ & $(1)+(2)$ & & 0.97 & -9.18 & -8.21 \\
\hline (5) & $\mathrm{W} \& \mathrm{U}$ & Case 1 vs. Case 4 & 3.47 & -16.59 & -13.12 \\
\hline (5) $)^{\prime}$ & $(2)+(3)$ & & 4.13 & -20.81 & -16.68 \\
\hline (6) & $F \& U$ & Case 1 vs. Case 6 & 3.37 & -14.09 & -11.89 \\
\hline (6) & $(1)+(3)$ & & 3.52 & -15.41 & -11.89 \\
\hline (7) & Group B & Case 1 vs. Case 8 & 3.49 & -16.59 & -13.10 \\
\hline (7) $)^{\prime}$ & $(1)+(2)+(3))$ & & 4.31 & -22.70 & -18.39 \\
\hline
\end{tabular}

- Comparison of the effects of building form

To compare the effects of building form, Case 1, which represents a building form, window system, and U-value characteristic of Group A, was compared with Case 5, whose building form represented Group B but whose window system and U-value represented Group A. Aspect ratios from 2.17:1 in Group A to 2.43:1 in Group B, indicated elongation. Floor area was approximately $5000 \mathrm{~m}^{2}$ less in 
Group B than in Group A; the total number of above the ground floor increased from 10 in Group A to 12 in Group B; and floor height became shorter, that is from $4.0 \mathrm{~m}$ in Group A to $3.9 \mathrm{~m}$ in Group B. These differences represent changes in building form that have caused the cooling load to increase by $0.18 \mathrm{kWh} / \mathrm{m}^{2}$ and the heating load to decrease by $1.89 \mathrm{kWh} / \mathrm{m}^{2}$ (Table 5 (1).

- Comparison of the effects of window systems

To compare the effects of window systems, Case 1, which represents a building form, window system, and U-value characteristic of Group A, was compared with Case 3, whose window system represented Group B but whose building form and U-value represented Group A. The results demonstrated that WWR was far less in Group B (27\%) than in Group A (45\%). In terms of the filling gas used for multi-pane glazing systems, air that was once used in conventional systems (i.e., Group A) has been replaced by argon, which was commonly used in Group B buildings. Given these design changes, the cooling load increased by $0.79 \mathrm{kWh} / \mathrm{m}^{2}$, whereas the heating load decreased by $7.29 \mathrm{kWh} / \mathrm{m}^{2}$ (Table 5 (2)).

\section{- Comparison of the effects of U-values}

To compare the effects of $\mathrm{U}$-values, Case 1, representing a building form, window system, and U-value characteristic of Group A, was compared with Case 2, whose U-values represented Group B but whose building form and window system represented Group A. The mean U-value decreased at all locations in Group A as compared to Group B, that is $0.393 \mathrm{~W} / \mathrm{m}^{2} \cdot \mathrm{K}$ to the $0.240 \mathrm{~W} / \mathrm{m}^{2} \cdot \mathrm{K}$ for exterior walls, from $0.215 \mathrm{~W} / \mathrm{m}^{2} \cdot \mathrm{K}$ to $0.138 \mathrm{~W} / \mathrm{m}^{2} \cdot \mathrm{K}$ at the roof, from $0.311 \mathrm{~W} / \mathrm{m}^{2} \cdot \mathrm{K}$ to $0.193 \mathrm{~W} / \mathrm{m}^{2} \cdot \mathrm{K}$ at the lowest floor, and from $2.478 \mathrm{~W} / \mathrm{m}^{2} \cdot \mathrm{K}$ to $1.403 \mathrm{~W} / \mathrm{m}^{2} \cdot \mathrm{K}$ at the window system. Given these changes in design, the cooling load increased by $3.34 \mathrm{kWh} / \mathrm{m}^{2}$, whereas the heating load decreased by $13.52 \mathrm{kWh} / \mathrm{m}^{2}$ (Table 5 (3).

- Comparison of the effects of combination of building form and window systems

To compare the effects of both building form and window systems, Case 1, which represented a building form, window system, and U-value characteristic of Group A, was compared with Case 7, whose building form and window system represented Group B but whose U-value represented Group A. Among the results, the cooling load increased by $1.01 \mathrm{kWh} / \mathrm{m}^{2}$, whereas the heating load decreased by $8.11 \mathrm{kWh} / \mathrm{m}^{2}$. Compared with the sum of (1) and (2), that result indicated a large increase in cooling load and a small decrease in heating load (Table 5 (4) and (4)').

- Comparison of the effects of combination of window systems and U-values

To compare the effects of window systems and U-values, Case 1, representing a building form, window system, and U-value characteristic of Group A, was compared with Case 4, whose window system and U-value represented Group B but whose building form represented Group A. Among the results, the cooling load increased by $3.47 \mathrm{kWh} / \mathrm{m}^{2}$, whereas the heating load decreased by $16.59 \mathrm{kWh} / \mathrm{m}^{2}$. Compared with the sum of (2) and (3), that result indicates a small increase in cooling load and a small reduction in heating load (Table 5 (5) and (5)').

- Comparison of the effects of combination of building form and U-values

To compare the effects building form and U-values, Case 1, representing a building form, window system, and U-value characteristic of Group A, was compared with Case 6, whose building form and $\mathrm{U}$-value represented Group B but whose window systems represented Group A. The results indicated that the cooling load increased by $3.37 \mathrm{kWh} / \mathrm{m}^{2}$, whereas the heating load decreased by $14.09 \mathrm{kWh} / \mathrm{m}^{2}$. Compared with the sum of (1) and (3), that result showed a small increase in cooling load and a small reduction in heating load (Table 5 (6) and (6)'). 
- Comparison of the two groups

To compare the effects of all three design factors simultaneously, Case 1, representing a building form, window system, and U-value characteristic of Group A, was compared with Case 8, whose all three values represented Group B. The cooling load was seen to increase by $3.49 \mathrm{kWh} / \mathrm{m}^{2}$, whereas the heating load decreased by $16.59 \mathrm{kWh} / \mathrm{m}^{2}$. Compared with the sum of (1), (2), and (3), that result indicates a small increase in cooling load and a small reduction in heating load (Table 5 (7) and (7)').

\section{Results and Discussion}

\subsection{Results}

Although the increase in cooling load was small in all cases, the combined total of cooling and heating loads decreased due to a large reduction in the heating load (see Table 5).

The results of analysis reveal that the greatest effects resulting from changes in building design have stemmed from different U-values, followed by window systems and building form (Table 5 (1)-(3)). As shown in Figure 9, U-values in relation to window systems contributed to the greatest changes.

The findings obtained by applying a combination of two elements (Table 5 (4)-(6) contradicted the prediction that the resulting values of the sum of the elements (Table 5 (1)-(3) would be identical to the load difference. In most cases, when two elements were applied in combination, the load difference was less than the simple sums of the two values. Similar results occurred in the case shown in Table 5 (7), in which all three elements were combined.

Contrary to the expectation that the greatest difference in load would be between Cases 1 and 8 (Table 5 (7)), the greater difference was between Cases 1 and 4 (Table 5 (5)), in which the building form represented Group A.

That finding indicates that, in designing office buildings, energy savings are greater in terms of cooling and heating loads if state-of-the-art technology in window systems and U-values is coupled with a conventional building form.

However, the design changes made due to the greenhouse gas reduction policy saved more energy in Case 8 compared to Case 1. Case 4 is the result of a detailed analysis of the design elements, but not a greenhouse gas reduction policy. While design guidelines for building forms can be provided, they cannot be established by greenhouse gas reduction policies. Design elements related to the building form (i.e., floor area, aspect ratio, number of floors, and floor height) are related to the conditions of the site on which the building is to be built and the subjective intention of the building owner. Case 4 offered the most energy savings; however, little difference was observed when compared to Case 8 $\left(0.02 \mathrm{kWh} / \mathrm{m}^{2}\right)$. If the number of samples changed is large, the statistical value is affected, and it has a big impact on the input data. This may change the overall ranking.

\subsection{Discussion}

\subsubsection{Contributions and Applications}

- South Korea's policy for reducing GHG emissions

With respect to the revised regulations for building designs in numerous countries, the South Korean government has implemented policies to strengthen the performance of insulation in newly constructed buildings. However, the analysis of designed buildings performed in this study revealed that not only the performance of insulation but also building forms and WWR have changed. If the performance of insulation alone was strengthened, then GHG emissions would have been reduced by about only 10\%, as shown in Table 5 (3); however, because building forms and WWR have also changed, an additional 3\% drop in emissions has been possible, as shown in Table 5 (7). Therefore, South Korea's policy of strengthening the performance of insulation in newly constructed buildings seems to have achieved sufficient positive effects, including by way of its derivative effects. 
Table 6 presents the yearly rates of reduction in GHG emissions calculated by the South Korean government since 2009, according to the expected BAU for 2020 [40]. At the national level, the average rate of reduced emissions was $13.3 \%$ for the period from 2015 to 2017, during which the rate for the building sector in particular was $12.8 \%$.

Table 6. Year-to-year rates of reductions in GHG emissions since 2009 in relation to the BAU predicted for 2020 [40].

\begin{tabular}{ccccc}
\hline \multirow{2}{*}{ Division } & \multicolumn{4}{c}{ Year-to-Year Rates of Reduction (\%) } \\
\cline { 2 - 5 } & $\mathbf{2 0 1 5}$ & $\mathbf{2 0 1 6}$ & $\mathbf{2 0 1 7}$ & Mean \\
\hline National & 10.0 & 13.8 & 16.2 & 13.3 \\
Building sector & 8.9 & 13.3 & 16.2 & 12.8 \\
\hline
\end{tabular}

Design changes that were incorporated, keeping in mind the GHG reduction policy, showed 13.1\% saving energy in Case 8 (reference building of Group B) than Case 1 (reference building of Group A). Savings in Case 8 was more than the average GHG reduction rate $(12.8 \%)$ compared to business as usual (BAU). In other words, given the changes in the design of buildings over time, achieving a $12.8 \%$ GHG emissions reduction in the building sector seems possible. In addition to this, results suggest that an additional increase in energy savings, energy performance, and air-conditioning efficiency could afford even greater potential for reducing GHG emissions by reducing the energy consumption of buildings.

Meanwhile, in the zero-energy building plan for newly constructed buildings, the South Korean government has established a roadmap with a phase-wise plan until 2025 [48], according to which the performance of insulation has already been enhanced. However, strengthening the performance of insulation can achieve only limited effects over time. Furthermore, the rates of such improvement have gradually decreased. With reference to the mean U-values of the exterior walls of buildings constructed in 2010 versus those built in 2016, the performance of insulation improved by about 37\%; however, from 2016 to 2018, the rate of improvement was only 4\%. At present, the performance of insulation in building envelopes reflects that of passive buildings and approaches that of zero-energy buildings.

Thus, new measures for reducing the GHG emissions of buildings need to be developed. Future policies should seek to improve the energy performance of existing buildings, enhance the efficiency of building operations, expand the distribution of new and renewable energies for buildings, establish infrastructure to share information about energy consumption in buildings, and promote the improvement of energy consumption in buildings which should be implemented together. At the same time, it is necessary for researchers to examine the effects of various policies for reducing GHG emissions by enhancing the energy efficiency of buildings.

\section{- $\quad$ Reference buildings}

The reference buildings developed in the study can also be used to review and evaluate alternatives in passive design technology applicable to office buildings and to analyze the sensitivity of parameters for policymaking and the assessment of energy efficiency in buildings.

\subsubsection{Limitations and Future Work}

GHG emissions caused by energy consumption in buildings are calculated by multiplying the consumption of each energy source by the emission factor of each source [6]. To do that, the amount of energy (e.g., electricity, gas, and city gas) required by HVAC systems and plant equipment are calculated. However, in this study, to analyze the effect of South Korean policy for reducing GHG emissions is observable in changes in building envelope design from an architectural perspective. 
Generally, primary energy consumption is calculated by considering the efficiency of the building's cooling and heating loads, as shown in Equations (1)-(3) [49].

$$
\begin{gathered}
E_{c}=\frac{\sum Q_{c}^{A}}{\eta_{c}}, \\
E_{h}=\frac{\sum Q_{h}^{A}}{\eta_{h}}, \\
E=E_{c}+E_{h}=\frac{\sum Q_{c}^{A}}{\eta_{c}}+\frac{\sum Q_{h}^{A}}{\eta_{h}},
\end{gathered}
$$

where, $E$ is the primary energy consumption $[\mathrm{kWh}], E_{c}$ is the primary cooling energy consumption $[\mathrm{kWh}], E_{h}$ is the primary heating energy consumption $[\mathrm{kWh}], Q_{c}^{A}$ is the annual building thermal load (cooling demand) [kWh], $Q_{h}^{A}$ is the annual building thermal load (heating demand) [kWh], $\eta_{c}$ is the system efficiency of HVAC (cooling), and $\eta_{h}$ is the system efficiency of HVAC (heating).

If the reduced rate of the cooling and heating loads of a building is known, then the reduced rate of energy consumption can be roughly identified. The reduced rate of the cooling and heating loads caused by changes to the design of building envelopes was analyzed and the results were used to estimate approximate reductions in GHG emissions. Similarly, energy savings in buildings with energy efficiency systems [50-53] (i.e., microgrid with renewable energy exchange, efficient power sharing within energy districts, robust energy scheduling, energy storage for communities, renewable energy technologies), energy sharing technologies [54-56], and zero-energy building technology [57] cannot be analyzed by the method proposed in this study. In other words, energy consumption with respect to energy efficiency and energy sharing, including HVAC system and plant equipment cannot be analyzed. However, the energy savings of these building envelopes can be analyzed by the method proposed in this study. Energy savings and rates may differ from the results of this study. This study focuses only on the trend of design elements of building envelopes and excludes HVAC system and plant equipment. Therefore, this study only compares energy demand, not energy consumption. However, accurate rates of reduced GHG emissions can be obtained by analyzing the total energy consumption of HVAC systems and plant equipment. This is a limitation of this study and a topic for further work. Accurate rates of reduced GHG emissions can be obtained by analyzing the total energy consumption of HVAC systems and plant equipment.

Meanwhile, it is necessary to develop a more detailed reference building that considers other elements of design (e.g., materials, equipment, and operations) and variables different from the three architectural elements considered in the study. If factors such as building use and location are also considered, then reduced GHG emissions by region can be analyzed, and the performance of such reductions can be quantified.

\section{Conclusions and Policy Implications}

This study involved the investigation of three elements in the design of building envelopes in office buildings for two periods and statistically treated these elements in combination. Case studies based on the combination of the elements were performed, and the results of eight combinations of the elements were compared and analyzed in terms of reductions in cooling and heating loads. In light of those results, the effects of South Korea's policy for reducing GHG emissions in the building sector were evaluated. The major results of the study are, as follows.

- Changes in the design of office buildings were evaluated by analyzing the statistical values of three design elements—building form, window systems, and U-values—for two periods: 2007-2011 (Group A) and 2015-2017 (Group B). Among the results, U-values showed the greatest variation, and WWR in relation to window systems shifted considerably. Between the two periods, building forms have become thinner and elongated due to changes in aspect ratio. 
- After a reference building for each of the three elements was developed, eight case studies were performed to analyze the various effects of changes in the elements compared to the reference building (i.e., Case 1), which contained elements characteristic of older buildings (i.e., Group A). Among the results, although the cooling load increased, the total energy load decreased due to the large reduction in the heating load.

- Although total building load savings were expected to be the largest in Case 8 (i.e., reference building for Group B), the largest load savings occurred in Case 4, with a building form representing Group A but window systems and U-values representing Group B. That finding suggests new office buildings can save more energy by using up-to-date window systems and insulation (i.e., represented by U-values) but maintaining the use of conventional building forms.

- Although the South Korean government has strengthened criteria for the design of insulation in new buildings, the results of the analysis indicate that building form and window systems have changed at the same time. A 10\% reduction in building load was achieved due to improved insulation, while an additional 3\% reduction was achieved by implementing changes in building forms and window systems.

- With changes in the design of building envelopes, achieving a $12.8 \%$ reduction in GHG emissions in the building sector is possible.

Although factors in the design of building envelopes continually change in response to policy for reducing GHG emissions, the strengthening of the performance of insulation has shown diminishing returned over time. Therefore, future policies should seek to improve the energy performance of existing buildings, enhance the efficiency of building operations, expand the distribution of new and renewable energies for buildings, establish infrastructure to share information about energy consumption in buildings, and promote the improvement of energy consumption in buildings which should be implemented together. However, there remains technological, economic and institutional uncertainty with regard to the introduction of these technologies in future residential building markets. To overcome such limitations, technological supply systems or policies need to be promoted at the national level [8]. Therefore, the South Korean government has established the second master plan of green buildings. In addition, various technologies are being developed. Especially, windows are one of the most important materials in a building. Therefore, window technologies (i.e., condensation resistance with ventilation system [58,59], vacuum window [60], and ventilated double skin windows [61]) are being developed for the South Korean climate.

Meanwhile, Group B has become a green building due to its architectural design changes. Improved energy efficiency certainly helps to reduce GHGs. However, as GHG emissions during the building life cycle cannot be mitigated, it is necessary to consider their mitigation by adding a lifecycle assessment method to green buildings [17,19-21].

Author Contributions: Conceptualization, Y.K., Y.-S.J.; data curation, Y.-S.J., T.-H.K.; funding acquisition, Y.-S.J., T.-H.K.; methodology, Y.K., J.-A.K., J.-H.H.; software, Y.K., J.-A.K.; resources, Y.-S.J., T.-H.K.; writing-original draft preparation, Y.K., J.-A.K., J.-H.H., T.-H.K., Y.-S.J.; writing-review and editing, Y.K., J.-H.H., Y.-S.J.; visualization, Y.K., J.-A.K.

Acknowledgments: This work was supported by the Urban Architecture Research Program, funded by the Ministry of Land, Infrastructure and Transport (No. 17AUDP-C127876-03); and the National Research Foundation of Korea (NRF) grant funded by the Korea government (No. NRF-2019R1I1A1A01060283).

Conflicts of Interest: The authors declare no conflict of interest. 


\section{Abbreviations}

$\begin{array}{ll}\text { Nomenclature } \\ E & \text { Primary energy consumption }[\mathrm{kWh}] \\ E_{c} & \text { Primary cooling energy consumption }[\mathrm{kWh}] \\ E_{h} & \text { Primary heating energy consumption [kWh] } \\ Q_{c}^{A} & \text { Annual building thermal load (cooling demand) } \\ & {[\mathrm{kWh}]} \\ Q_{h}^{A} & \text { Annual building thermal load (heating demand) } \\ \eta_{c} & \text { [kWh] } \\ \eta_{h} & \text { System efficiency of HVAC (cooling) } \\ \text { Acronyms and Abbreviations } \\ \text { BAU } & \text { Business as usual } \\ \text { GHG } & \text { Greenhouse gas } \\ \text { HVAC } & \text { Heating, ventilation, and air conditioning } \\ \text { LEAP } & \text { Long-Range Energy Alternative Planning } \\ \text { U-value } & \text { Overall heat transfer coefficient }\end{array}$

\section{References}

1. Kim, H.K. The Right Way to Know about Green Growth; Nanam Publishing House: Gyeonggi-Do, Korea, 2011.

2. Graham, P. Sustainable Buildings and Climate Initiative. Draft Briefing on the Sustainable Building Index; UNEP SBCI: Paris, France, 2010.

3. UNEP. Building and Climate Change: Summary for Decision-Makers; United Nations Environment Programme; UNEP: Nairobi, Kenya, 2009.

4. Corgnati, S.P.; Fabrizio, E.; Filippi, M.; Monetti, V. Reference buildings for cost optimal analysis: Method of definition and application. Appl. Energy 2013, 102, 983-993. [CrossRef]

5. Intergovernmental Panel on Climate Change. Fifth Assessment Report; Intergovernmental Panel on Climate Change: Geneva, Switzerland, 2014.

6. Kim, T.H.; Jeong, Y.S. Analysis of energy-related greenhouse gas emission in the Korea's building sector: Use national energy statistics. Energies 2018, 11, 855. [CrossRef]

7. Intergovernmental Panel on Climate Change. Fourth Assessment Report; Intergovernmental Panel on Climate Change: Geneva, Switzerland, 2007.

8. Jeong, Y.-S. Assessment of Alternative Scenarios for $\mathrm{CO}_{2}$ Reduction Potential in the Residential Building Sector. Sustainability 2017, 9, 394. [CrossRef]

9. Korean Government. Amendment of 2030 National GHG Emissions Reduction Roadmap; Korean Government: Sejong, Korea, 2018. (In Korean)

10. Cuce, E. Accurate and reliable U-value assessment of argon-filled double glazed windows: A numerical and experimental investigation. Energy Build. 2018, 171, 100-106. [CrossRef]

11. EnergyPlus. Available online: https://energyplus.net/ (accessed on 13 March 2019).

12. OpenStudio. Available online: https://www.openstudio.net (accessed on 13 March 2019).

13. Yu, S.; Eom, J.; Evans, M.; Clarke, L. A long-term, integrated impact assessment of alternative building energy code scenarios in China. Energy Policy 2014, 67, 626-639. [CrossRef]

14. Tan, X.; Lai, H.; Gu, B.; Zeng, Y.; Li, H. Carbon emission and abatement potential outlook in China's building sector through 2050. Energy Policy 2018, 118, 429-439. [CrossRef]

15. Wang, H.; Chen, W.; Shi, J. Low carbon transition of global building sector under 2- and 1.5-degree targets. Appl. Energy 2018, 222, 148-157. [CrossRef]

16. Wang, T.; Foliente, G.; Song, X.; Xue, J.; Fang, D. Implications and future direction of greenhouse gas emission mitigation policies in the building sector of China. Renew. Sustain. Energy Rev. 2014, 31, 520-530. [CrossRef]

17. Jeong, Y.S.; Lee, S.E.; Huh, J.H. Estimation of $\mathrm{CO}_{2}$ emission of apartment buildings due to major construction materials in the Republic of Korea. Energy Build. 2012, 49, 437-442. [CrossRef] 
18. Zhao, S.; Song, Q.; Duan, H.; Wen, Z.; Wang, C. Uncovering the lifecycle GHG emissions and its reduction opportunities from the urban buildings: A case study of Macau. Resour. Conserv. Recycl. 2019, 147, $214-226$. [CrossRef]

19. Cellura, M.; Guarino, F.; Longo, S.; Mistretta, M. Modeling the energy and environmental life cycle of buildings: A co-simulation approach. Renew. Sustain. Energy Rev. 2017, 80, 733-742. [CrossRef]

20. Wang, T.; Seo, S.; Liao, P.C.; Fang, D. GHG emission reduction performance of state-of-the-art green buildings: Review of two case studies. Renew. Sustain. Energy Rev. 2016, 56, 484-493. [CrossRef]

21. Chau, C.K.; Hui, W.K.; Ng, W.Y.; Powell, G. Assessment of $\mathrm{CO}_{2}$ emissions reduction in high-rise concrete office buildings using different material use options. Resour. Conserv. Recycl. 2012, 61, 22-34. [CrossRef]

22. Iwaro, J.; Mwasha, A. A review of building energy regulation and policy for energy conservation in developing countries. Energy Policy 2010, 38, 7744-7755. [CrossRef]

23. TABULA Project Team. Use of Building Typologies for Energy Performance Assessment of National Building Stocks. Existent Experiences in European Countries and Common Approach. First TABULA Synthesis Report; Institut Wohnen und Umwelt GmbH: Darmstadt, Germany, 2010; Available online: http://www.building-typology. eu/downloads/public/docs/report/TABULA_SR1.pdf (accessed on 8 November 2019).

24. ASIEPI. Comparison of Energy Performance Requirements Levels: Possibilities and Impossibilities. Summary Report; Report of Assessment and Improvement of the EPBD Impact (ASIEPI); ASIEPI Project: Pan European, 2010; Available online: https://www.buildup.eu/sites/default/files/content/ASIEPI_Intercomparison_ SummaryReport_0.pdf (accessed on 8 November 2019).

25. Deru, M.; Field, K.; Studer, D.; Benne, K.; Griffith, B.; Torcellini, P.; Liu, B.; Halverson, M.; Winiarski, D.; Rosenberg, M.; et al. Department of Energy Commercial Reference Building Models of the National Building Stock; Technical Report NREL/TP-5500-46861; NREL: Golden, CO, USA, 2011.

26. Kim, D.W.; Kim, Y.M.; Lee, S.H.; Park, W.Y.; Bok, Y.J.; Ha, S.K.; Lee, S.E. Development of Reference Building Energy Models for South Korea. In Proceedings of the 15th IBPSA Conference, San Francisco, CA, USA, 7-9 August 2017.

27. Schaefer, A.; Ghisi, E. Method for obtaining reference buildings. Energy Build. 2016, 128, 660-672. [CrossRef]

28. Brandão De Vasconcelos, A.; Pinheiro, M.D.; Manso, A.; Cabaço, A. EPBD cost-optimal methodology: Application to the thermal rehabilitation of the building envelope of a Portuguese residential reference building. Energy Build. 2016, 111, 12-25. [CrossRef]

29. Bhatnagar, M.; Mathur, J.; Garg, V. Development of reference building models for India. J. Build. Eng. 2019, 21, 267-277. [CrossRef]

30. Buso, T.; Corgnati, S.P. A customized modelling approach for multi-functional buildings-Application to an Italian Reference Hotel. Appl. Energy 2017, 190, 1302-1315. [CrossRef]

31. Brandão de Vasconcelos, A.; Cabaço, A.; Pinheiro, M.D.; Manso, A. The impact of building orientation and discount rates on a Portuguese reference building refurbishment decision. Energy Policy 2016, 91, 329-340. [CrossRef]

32. Brandão de Vasconcelos, A.; Pinheiro, M.D.; Manso, A.; Cabaço, A. A Portuguese approach to define reference buildings for cost-optimal methodologies. Appl. Energy 2015, 140, 316-328. [CrossRef]

33. Li, J.; Ng, S.T.; Skitmore, M. Review of low-carbon refurbishment solutions for residential buildings with particular reference to multi-story buildings in Hong Kong. Renew. Sustain. Energy Rev. 2017, 73, $393-407$. [CrossRef]

34. Ballarini, I.; Corgnati, S.P.; Corrado, V. Use of reference buildings to assess the energy saving potentials of the residential building stock: The experience of TABULA project. Energy Policy 2014, 68, 273-284. [CrossRef]

35. Shabunko, V.; Lim, C.M.; Mathew, S. EnergyPlus models for the benchmarking of residential buildings in Brunei Darussalam. Energy Build. 2018, 169, 507-516. [CrossRef]

36. Dino, I.G.; Stouffs, R. Evaluation of reference modeling for building performance assessment. Autom. Constr. 2014, 40, 44-59. [CrossRef]

37. Chen, Y.; Hong, T. Impacts of building geometry modeling methods on the simulation results of urban building energy models. Appl. Energy 2018, 215, 717-735. [CrossRef]

38. Chen, Y.; Hong, T.; Luo, X.; Hooper, B. Development of city buildings dataset for urban building energy modeling. Energy Build. 2019, 183, 252-265. [CrossRef]

39. Kazas, G.; Fabrizio, E.; Perino, M. Energy demand profile generation with detailed time resolution at an urban district scale: A reference building approach and case study. Appl. Energy 2017, 193, 243-262. [CrossRef] 
40. Korean Government. 2020 National GHG Emissions Reduction Roadmap; Korean Government: Sejong, Korea, 2014. (In Korean)

41. Korean Government. Greenhouse Gas Reduction Targets by Sectors and Years; Korean Government: Seoul, Korea, 2011. (In Korean)

42. Korean Government. The National Roadmap to Achieve the National Greenhouse Gas Emissions Reduction Target. Available online: http://me.go.kr/home/web/board/read.do?pagerOffset=0\& maxPageItems=10\&maxIndexPages=10\&searchKey=\&searchValue=\&menuId=286\&orgCd=\&boardId= 339265\&boardMasterId=1\&boardCategoryId=\&decorator= (accessed on 8 November 2019). (In Korean)

43. Arıc1, M.; Kan, M. An investigation of flow and conjugate heat transfer in multiple pane windows with respect to gap width, emissivity and gas filling. Renew. Energy 2015, 75, 249-256. [CrossRef]

44. Muneer, T.; Han, B. Simplified analysis for free convection in enclosures-Application to an industrial problem. Energy Convers. Manag. 1996, 37, 1463-1467. [CrossRef]

45. U.S. Department of Energy. EnergyPlus Version 8.9.0 Documentation, Input Output Reference; U.S. Department of Energy: Washington, DC, USA, 2018. Available online: https://energyplus.net/sites/all/modules/custom/ nrel_custom/pdfs/pdfs_v8.9.0/InputOutputReference.pdf (accessed on 8 November 2019).

46. U.S. Department of Energy. EnergyPlus, Input Output Reference. The Encyclopedic Reference to EnergyPlus Input and Output; U.S. Department of Energy: Washington, DC, USA, 2018. Available online: https: //energyplus.net/sites/default/files/pdfs/pdfs_v8.3.0/InputOutputReference.pdf (accessed on 8 November 2019).

47. Al-janabi, A.; Kavgic, M.; Mohammadzadeh, A.; Azzouz, A. Comparison of EnergyPlus and IES to model a complex university building using three scenarios: Free-floating, ideal air load system, and detailed. J. Build. Eng. 2019, 22, 262-280. [CrossRef]

48. International Energy Agency. Energy Policies of IEA Countries: Republic of Korea 2012 Review; International Energy Agency: Paris, France, 2012.

49. Cho, J.; Kim, J.; Lee, S.; Koo, J. A bi-directional systematic design approach to energy optimization for energy-efficient buildings. Energy Build. 2016, 120, 135-144. [CrossRef]

50. Carli, R.; Dotoli, M. Decentralized control for residential energy management of a smart users' microgrid with renewable energy exchange. IEEE/CAA J. Autom. Sin. 2019, 6, 641-656. [CrossRef]

51. Giordano, A.; Mastroianni, C.; Menniti, D.; Pinnarelli, A.; Scarcello, L.; Sorrentino, N. A Two-Stage Approach for Efficient Power Sharing Within Energy Districts. IEEE Trans. Syst. Man Cybern. Syst. 2019, 1-11. [CrossRef]

52. Hosseini, S.M.; Carli, R.; Dotoli, M. Robust Day-Ahead Energy Scheduling of a Smart Residential User Under Uncertainty. In Proceedings of the 2019 18th European Control Conference (ECC), Naples, Italy, 25-28 June 2019; pp. 935-940.

53. Parra, D.; Swierczynski, M.; Stroe, D.I.; Norman, S.A.; Abdon, A.; Worlitschek, J.; O’Doherty, T.; Rodrigues, L.; Gillott, M.; Zhang, X.; et al. An interdisciplinary review of energy storage for communities: Challenges and perspectives. Renew. Sustain. Energy Rev. 2017, 79, 730-749. [CrossRef]

54. Murphy, A.R.; Fung, A.S. Techno-economic study of an energy sharing network comprised of a data centre and multi-unit residential buildings for cold climate. Energy Build. 2019, 186, 261-275. [CrossRef]

55. Roberts, M.B.; Bruce, A.; Macgill, I. Impact of shared battery energy storage systems on photovoltaic selfconsumption and electricity bills in apartment buildings. Appl. Energy 2019, 245, 78-95. [CrossRef]

56. Quddus, A.; Shahvari, O.; Marufuzzaman, M.; Usher, J.M.; Jaradat, R. A collaborative energy sharing optimization model among electric vehicle charging stations, commercial buildings, and power grid. Appl. Energy 2018, 229, 841-857. [CrossRef]

57. Vares, S.; Häkkinen, T.; Ketomäki, J.; Shemeikka, J.; Jung, N. Impact of renewable energy technologies on the embodied and operational GHG emissions of a nearly zero energy building. J. Build. Eng. 2019, 22, 439-450. [CrossRef]

58. Shin, M.S.; Rhee, K.-N.; Lee, E.-T.; Jung, G.-J. Performance evaluation of $\mathrm{CO}_{2}$-based ventilation control to reduce $\mathrm{CO} 2$ concentration and condensation risk in residential buildings. Build. Environ. 2018, 142, 451-463. [CrossRef]

59. Park, S.; Koo, S.Y.; Lim, J.H.; Seong, Y.B.; Song, S.Y. Condensation Resistance Evaluation of a Double-sliding Window System for Apartment Buildings. Procedia Eng. 2016, 146, 60-68. [CrossRef] 
60. Cho, S. Analysis of the performance of vacuum glazing in office buildings in Korea: Simulation and experimental studies. Sustainability 2017, 9, 936. [CrossRef]

61. Koo, B.; Lee, K.; An, Y.; Lee, K. Solar heat gain reduction of ventilated double skin windows without a shading device. Sustainability 2018, 10, 64. [CrossRef] 